\title{
Towards a broad-based and holistic framework of Sustainable Intensification indicators
}

\author{
N. Mahon ${ }^{\text {a }}$ I. Crute ${ }^{\mathrm{b}}$, M. Di Bonito ${ }^{\mathrm{a}}$, E.A. Simmons ${ }^{\mathrm{c}}$, M.M. Islam ${ }^{\mathrm{a}} *$ \\ ${ }^{a}$ School of Animal, Rural and Environmental Sciences, Nottingham Trent University, Brackenhurst, Southwell, Nottingham NG 25 OQF, UK \\ ${ }^{b}$ Agriculture \& Horticulture Development Board, Stoneleigh Park, Warwickshire, UK \\ ${ }^{c}$ Nottingham Trent University Directorate, 50 Shakespeare Street, Nottingham, Nottinghamshire, UK
}

\section{A R T I C L E I N F O}

\section{Keywords:}

Agriculture

Indicators

Social-Ecological Systems

Stakeholder views

Sustainable intensification

\begin{abstract}
A B S T R A C T
The concept of 'Sustainable Intensification' (SI) has been promoted as a potential solution to the many contemporary challenges facing agriculture, but has also received widespread criticism for being too narrow in scope and failing to address all aspects of sustainability. Despite this, there are few suggestions in the literature as to what a holistic, broad-based approach to SI should comprise and what issues and trade-offs are likely to arise in the adoption and operation of such a broadly-based approach. We report a suit of SI indicators suggested by UK stakeholders, evaluate the plausibility of these in terms of the commonly established principles of sustainability, and identify the critical issues that may arise in the adoption and operation of these indicators. The purpose of this paper is not to recommend a specific blueprint for SI but to raise issues and questions for dialogue amongst stakeholders. Data were collected via semi-structured interviews with 32 stakeholders from throughout the UK agrifood system. The data were analysed thematically and organised using a Social-Ecological Systems (SESs) framework. The interviewees suggested a total of 110 SI indicators, of which the most frequently suggested related to agricultural production and ecological considerations. There was less emphasis placed on social and cultural dimensions of agricultural systems. A number of the indicators suggested were poorly-defined and it was difficult to determine what particular aspects of sustainability they addressed. Many potential trade-offs between the indicators were also evident. The findings raise a number of questions. Is it appropriate to continue referring to SI as Sustainable Intensification when it fails to give equal consideration to all accepted aspects of sustainability? Would it be more appropriate to refer to the SI concept as 'Ecological Intensification'? Is a broad-based and all-encompassing definition of 'sustainability' always desirable, or should 'sustainability' be considered as context specific, with the weighting of the different dimensions varying according to operational circumstances? We argue that these questions need to be resolved through stakeholder dialogues in order for the concept of SI to become more widely accepted and implementable in practice.
\end{abstract}

\section{Introduction}

Contemporary agriculture is facing multiple, competing expectations. On the one hand, it is expected to produce more for a growing global population amidst increasingly scarce natural resources and the challenges of climate change (Beddington, 2009; Godfray et al., 2010; Hunter et al., 2017). On the other hand, it must also be more sustainable (Altieri, 2004; Hoffmann, 2011; National Research Council and National Research Council, 2010; Pretty et al., 2008; Royal Society, 2009; Tilman et al., 2002; Whitfield et al., 2015). However, many argue that the quest for increased production may not be com- patible with the goals of sustainability (Gliessman, 2014; Godfray, 2015; Loos et al., 2014).

The concept of 'Sustainable Intensification' (SI) has been posited by some as a solution to the above challenges (Pretty, 1997; Sutherland et al., 2015; Vanlauwe et al., 2014). It is viewed by some as a third paradigm of global agricultural development (Islam et al., 2013; Jordan and Davis, 2015). This paradigm is thought to represent a middle way between, on one hand, 'industrial agriculture', typified by the use of monocultures of high-yielding crops and livestock and the extensive use of agrochemicals and farm machineries (Douthwaite et al., 2003; International Food Policy Research Institute, 2002); and on the other

\footnotetext{
* Corresponding author.

Email addresses: niamh.mahon@ntu.ac.uk (N. Mahon); Ian.Crute@ahdb.org.uk, ian.crute@icloud.com (I. Crute); marcello.dibonito@ntu.ac.uk (M. Di Bonito); eunice.simmons@ntu. ac.uk (E.A. Simmons); mofakkarul.islam@ntu.ac.uk (M.M. Islam)
} 
hand, 'alternative agriculture', characterised by localised, small-scale systems, based on agroecological principles and the use of minimal, or no external inputs (Altieri, 2004; Pimentel et al., 2005; Pretty, 1995; Raynolds, 2000; Vandermeer, 1995). Since its inception in the nineties (Pretty, 1997), SI has attracted diverse stakeholders, including: national governments (DEFRA SIP, 2016, 2015), policy think tanks (Foresight, 2011; Royal Society, 2009), intergovernmental organizations (FAO, 2011; World Bank et al., 2013), research institutes (Buckwell et al., 2014; The Montpellier Panel, 2013), and transnational agribusinesses (Syngenta foundation for sustainable agriculture, 2016).

Nevertheless, SI has become a contested concept with regard to its precise meaning, means of implementation, and desired outcomes (Garnett and Godfray, 2012; Mahon et al., 2017). Reviews of these debates (Bernard and Lux, 2017; Campbell et al., 2014; Gliessman, 2014; Godfray, 2015; Loos et al., 2014; Petersen and Snapp, 2015) suggest that the most contentious aspect of SI is the sustainability dimension. Whilst some - e.g., the UK Royal Society and the Foresight report on food and farming - define SI as producing more from the same area of land while reducing the environmental impacts of agriculture (Foresight, 2011; Royal Society, 2009), others express concerns that this definition is too narrow and does not adequately address the social dimensions of sustainability. Many civil society organisations are therefore sceptical (Collins and Chandrasekaran, 2012; Cook et al., 2015). These authors argue that SI favours the powerful to the detriment of smallholder farmers and the wider public (Collins and Chandrasekaran, 2012; Cook et al., 2015; Lewis-Brown and Lymberry, 2012). Others label SI as an "oxymoron", stating that intensification is not compatible with sustainability (Lewis-Brown and Lymberry, 2012: 1). Similarly, a recent review (Mahon et al., 2017) of SI indicators finds that the social dimensions are under-represented in the global literature. Loos et al. (2014) mention that the term SI is a misnomer, as its current productivist interpretation does not engage with established principles of sustainability. Gliessman (2014) concludes that there is a need for a holistic approach to SI by integrating agronomic and ecological sustainability with social, economic, and cultural sustainability.

Despite such criticisms and expectations, there are few suggestions as to what holistic, broad-based approaches to SI might look like and what issues and trade-offs would arise in the adoption and operation of such approaches. The issue of trade-offs is especially important since sustainability itself is a highly contested term, often involving compromises between its components (Ayres et al., 1998; McShane et al., 2011). Moreover, debates about what SI should or should not be have largely been top-down, reflecting a multitude of individual opinions. Attempts to contextualise such debates based on the opinions of multiple stakeholders are rare. A bottom-up and stakeholder-sensitive approach is important, since insights from agency-oriented sustainability transition theories (see Geels, 2010) suggest that the absence of a shared vision among key stakeholders may hamper successful transitions to sustainability. This is especially true for concepts that are ambiguous and contested, as is the case of SI.

In this paper we intend to:

- apply a holistic, systems framework to identify the indicators of SI from the viewpoints of UK stakeholders;

- evaluate the plausibility of the indicators in terms of the commonly established principles of sustainability; and

- identify the critical issues that may arise in the adoption and operation of the suggested indicators.

The purpose of this paper is not to recommend a particular blueprint for SI but to raise issues and questions for dialogue among stakeholders.

\section{Analytical framework and methods}

In the literature, SI indicators have been considered largely based on limited aspects of agriculture, in particular, 'outcomes' (Mahon et al., 2017). Such approaches can be of limited use from a policy point of view. Although it is important to identify expected outcomes from agricultural systems (e.g., increased crop yield), it is equally important to understand the processes (e.g. use of hybrid crop varieties, application of agrochemicals, etc.) required to produce such outcomes, as well as the conditions (e.g. soil fertility, water availability, etc.) under which such processes may be applicable. This necessitates the development of a holistic, systems-based approach. Such thinking is not new in agriculture, e.g., the Farming Systems Research (FSR) approach came to prominence in the 1970s (Bawden, 1995; McCown, 2001; Norman, 1978; Simmonds, 1985). However, agricultural systems have traditionally been conceptualised as ecological systems, e.g., crop systems modelling (Holzworth et al., 2014; Jones et al., 2003; Keating et al., 2003; Stöckle et al., 2003, 2014), with little consideration of the social elements. Nevertheless, there are increasing calls for other dimensions of to be given consideration (Prokopy et al., 2008; Willock et al., 1999b).

In order to capture UK stakeholder prescriptions of SI indicators we conceptualised agriculture as Social-Ecological Systems (SESs) and applied an adapted version of an SES framework developed by Ostrom and colleagues (McGinnis and Ostrom, 2014; Ostrom, 2007a,b; Ostrom, 2009; Ostrom and Cox, 2010) to guide data collection and analysis. This framework states that the complex outcomes of SESs (e.g., sustainability and equity) are the function of both the ecological and the human components, and the interactions between these components (Ostrom, 2007a,b; Ostrom, 2009; Vogt et al., 2015). Although this framework was devised primarily for the investigation of common-pool resources, e.g., forests and fisheries (Anderies et al., 2004; Basurto et al., 2013; Hinkel et al., 2015; Nagendra and Ostrom, 2014), it has been applied to agricultural systems as well (Halliday and Glaser, 2011; Hanspach et al., 2017; Lescourret et al., 2015; Mahon et al., 2017).

In Ostrom's framework, SESs are conceptualised as comprising seven sub-systems (Fig. 1). The 'Resource System', e.g., a designated national park, or a demarcated fishery (Ostrom et al., 2007; Ostrom, 2009), comprises the characteristics of the SES as a whole, e.g., its predictability and location (Ostrom, 2009). It is suggested that more predictable systems are more sustainable, as users are more able to es-

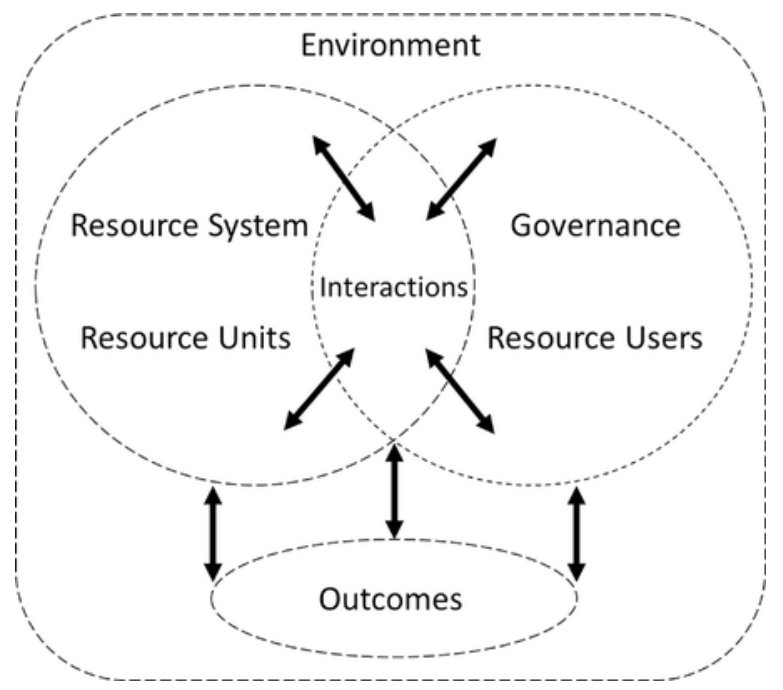

Fig. 1. A diagrammatic representation of the SES framework (adapted from Ostrom, 2009). 
timate how much of a resource can be extracted each year (Ostrom, 2009). The 'Resource Units' meanwhile are the individual variables that make up the 'Resource System' (Basurto et al., 2013). These include the biotic components (e.g., individual plants and animals), abiotic components (e.g., the volume and flow of water within a river), and their characteristics (e.g., growth rate and economic value) (Ostrom, 2009). It is suggested that a high degree of knowledge of the Resource Units is required for sustainable harvesting (Ostrom et al., 2007). Together, these represent the 'ecological' components. They set the conditions by which agriculture operates, e.g., a farmer is constrained in what type of agriculture can be performed by the type (or types) of soil present, or the presence or absence of water sources.

In addition, there are constraints and opportunities set by the social components ('Resource users' and 'Governance') of such systems (Basurto et al., 2013). Examples may include rules in place on technologies that can be used, or property rights. The SES literature indicates that if such rules are not appropriate for the ecological conditions then long-term sustainability is unlikely to be achieved (Ostrom, 2009).'

Resource users' include the people that use the Resource System for commercial or recreational purposes and their socioeconomic attributes (McGinnis and Ostrom, 2014; Ostrom, 2009). Examples of the 'Governance' sub-system include the constitutional rules concerning how the Resource System can be used, as well as the organisations that manage the Resource System (Ostrom, 2009; Ostrom and Cox, 2010).

'Interactions' occur between and within the above components, e.g., the harvesting of resources by Resource users (McGinnis and Ostrom, 2014; Ostrom, 2009). Some suggest that Ostrom's SES framework takes too narrow a view of 'Interactions' (Vogt et al., 2015) as it focuses on interactions between social variables, with less emphasis on the interactions within the ecological sub-system (Mahon et al., 2017; Vogt et al., 2015). In order to address this we acknowledge that interactions can occur within and between all of the SES components. For example, farm management practices such as irrigation activities are an interaction between the human and the environmental components of an agricultural system.

The above sub-systems can be thought of as the conditions and processes required to produce certain 'Outcomes'. These include social performance measures, such as efficiency and equity; ecological performance measures, such as resilience and overharvesting; and externalities to other SESs (Ostrom, 2009). In agriculture, the focus has traditionally been on optimising outcomes related to 'provisioning services' - the production of food, fuel, and fibre (Zhang et al., 2007). Nevertheless, the concept of 'multifunctional agriculture' has gained traction (Dobbs and Pretty, 2004; Renting et al., 2009) and considers a range of other outcomes that agriculture provides, i.e., regulating services (e.g., pollination, flood mitigation), supporting services (e.g., soil formation, nutrient cycling), and cultural services (e.g. the preservation of cultural heritage) (Dobbs and Pretty, 2004; Levrel et al., 2009; Maier et al., 2001; Shobayashi et al., 2003). In addition, there may be 'ecosystem disservices' (Ango et al., 2014). These include functions that reduce the productivity of agriculture, or increase the cost of production, e.g., the prevalence of crop pests (Zhang et al., 2007), as well as declines in agrobiodiversity.

Finally, the SES of interest is conceptualised as operating within an 'Environment' comprising the social, political and economic settings (Basurto et al., 2013), e.g., climate, political stability and market incentives (Ostrom, 2009). For agriculture, this could include consumer food purchasing behaviour (Food Ethics Council (Great Britain), 2007), international trade regimes (Food Ethics Council (Great Britain), 2010) and international conventions (Wray, 2016).

Based on the above, the sustainability of agricultural systems can be thought of as the ability of the system to continue providing the de- sired 'outcomes', without undermining the potential of the 'enabling conditions' and 'processes' required to continue supplying these outcomes (United Nations, 1987). We use the generic term 'indicator' to describe these attributes, processes, and outcomes.

Data for this study were collected during 2015-16 through semi-structured interviews with 32 purposively sampled stakeholders from across the UK agrifood system (Table 1). The stakeholders included those who had engaged with SI (e.g., wrote online articles, discussed SI in organisational websites, published journal articles, participated in SI events, and were members of SI-related organisations) and were likely to be influenced by (e.g., farmers, input suppliers, and food retailers), or could influence (e.g., academics, and government and non-government organisations) the implementation of SI in the UK. The individuals were identified via snowball sampling (Goodman, 1961), with the first interviewees identified through a literature review and the successive interviewees through referrals by those who had already been interviewed.

The interviews were conducted either face-to-face or via telephone, at the stakeholders' discretion. Informed consent were obtained from all of the interviewees and all procedures were conducted in accordance with relevant institutional ethical standards.

The participants were asked to suggest the indicators which they believed should be used to measure SI in the UK, the scales at which those indicators should be measured, and whether each indicator was positive (should increase/improve under SI) or negative (should decrease under SI). The participants were provided with a diagram visualising agriculture as an SES and were prompted to think about SI and indicators that could be used to measure SI in consideration of the SES framework. The interviews were audio recorded and transcribed verbatim and the data were analysed thematically (Braun and Clarke et al., 2012) according to the concepts outlined in the SESs framework (Fig. 1). NVIVO 10 software (QSR International, 2012) was used for the analysis. Participant sampling was terminated when 'data saturation' had been reached (see, Fusch and Ness, 2015; Marshall, 1996; Mason, 2010, for the concept of data saturation). The plausibility of the indicators originating from the qualitative analysis were then evaluated in terms of the commonly established principles of sustainability in the literature on sustainability and sustainable agriculture.

\section{The Sustainable Intensification indicators and their evaluation}

\subsection{Resource system}

In total, ten indicators were suggested for this sub-system, four of these were niche concerns, mentioned by less than three of the participants. As shown in Table 2, 'Productivity of agriculture', was the most frequently suggested indicator. Productivity is defined as the return from each unit of resource invested (Zepeda, 2001). Many proponents

Table 1

UK stakeholder groups interviewed in this investigation.

\begin{tabular}{ll}
\hline Stakeholder group & No. of Interviewees \\
\hline Academia & 6 \\
Government organisation & 2 \\
NGO (conservation) & 4 \\
NGO (agriculture) & 8 \\
NGO (animal rights) & 2 \\
NGO (sustainability) & 2 \\
Agricultural levy board & 1 \\
Advisory service provider & 1 \\
Input supplier & 2 \\
Farmer & 3 \\
Food retailer & 1 \\
Total & $\mathbf{3 2}$ \\
\hline
\end{tabular}


Table 2

SI indicators suggested within the 'Resource System' sub-system.

\begin{tabular}{|c|c|c|c|c|c|c|}
\hline Indicator name & $\begin{array}{l}\text { Positive or } \\
\text { Negative }\end{array}$ & Scale(s) & $\begin{array}{l}\text { No. of } \\
\text { Interviewees }\end{array}$ & $\begin{array}{l}\text { Stakeholder } \\
\text { group(s) }\end{array}$ & Plausibility re: sustainability & Potential trade-offs and issues \\
\hline $\begin{array}{l}\text { Productivity of } \\
\text { agriculture }\end{array}$ & Positive & National & 19 & $\begin{array}{l}\text { Mainly NGOs, } \\
\text { farmers, food } \\
\text { retailers }\end{array}$ & Economic sustainability & $\begin{array}{l}\text { Vaguely defined, which could } \\
\text { lead to confusion; } \\
\text { narrow focus may create } \\
\text { potential trade-offs with } \\
\text { environmental and social } \\
\text { sustainability }\end{array}$ \\
\hline $\begin{array}{l}\text { Area of land } \\
\text { under } \\
\text { agricultural } \\
\text { production }\end{array}$ & Negative & National & 10 & $\begin{array}{l}\text { Mainly NGOs } \\
\text { and farmers }\end{array}$ & $\begin{array}{l}\text { Environmental sustainability } \\
\text { if the 'spared' land is used } \\
\text { for conservation }\end{array}$ & $\begin{array}{l}\text { Intensification of remaining } \\
\text { agricultural land could lead } \\
\text { to localised potential trade- } \\
\text { offs with environmental } \\
\text { sustainability; } \\
\text { Unclear as to the governance } \\
\text { mechanisms required to } \\
\text { ensure this 'spared' land is } \\
\text { used for conservation }\end{array}$ \\
\hline Size of farms & $\begin{array}{l}\text { Positive, } \\
\text { Negative }\end{array}$ & National & 9 & $\begin{array}{l}\text { Mainly NGOs, } \\
\text { academics, food } \\
\text { retailers }\end{array}$ & $\begin{array}{l}\text { Larger farms for economic } \\
\text { sustainability; small farms for } \\
\text { social sustainability and } \\
\text { potentially environmental } \\
\text { sustainability }\end{array}$ & $\begin{array}{l}\text { Potential trade-offs between } \\
\text { small and large farms }\end{array}$ \\
\hline $\begin{array}{l}\text { Area of high } \\
\text { nature value } \\
\text { farmland }\end{array}$ & Positive & National & 7 & Mainly NGOs & $\begin{array}{l}\text { Environmental and social } \\
\text { sustainability }\end{array}$ & $\begin{array}{l}\text { Potential trade-offs with } \\
\text { economic sustainability }\end{array}$ \\
\hline $\begin{array}{l}\text { Area of irrigated } \\
\text { land }\end{array}$ & Unassigned & $\begin{array}{l}\text { Farm, } \\
\text { landscape }\end{array}$ & 3 & $\begin{array}{l}\text { Mainly } \\
\text { agricultural } \\
\text { input suppliers }\end{array}$ & $\begin{array}{l}\text { Economic and environmental } \\
\text { sustainability, but this will } \\
\text { depend on the technology } \\
\text { and water source used }\end{array}$ & $\begin{array}{l}\text { Vaguely defined; potential } \\
\text { trade-offs with environmental } \\
\text { sustainability, depending on } \\
\text { the technology and water } \\
\text { source used }\end{array}$ \\
\hline $\begin{array}{l}\text { Length of } \\
\text { hedgerows per } \\
\text { hectare }\end{array}$ & Positive & Farm & 3 & Mainly NGOs & $\begin{array}{l}\text { Environmental sustainability, } \\
\text { potentially social and } \\
\text { economic sustainability }\end{array}$ & $\begin{array}{l}\text { May act as a reservoir of } \\
\text { agricultural pests and weeds }\end{array}$ \\
\hline $\begin{array}{l}\text { Degree of } \\
\text { habitat } \\
\text { connectivity }\end{array}$ & Positive & Landscape & 2 & $\begin{array}{l}\text { Academia, } \\
\text { Government } \\
\text { organisation }\end{array}$ & Environmental sustainability & Niche concern \\
\hline $\begin{array}{l}\text { Length of } \\
\text { footpaths and } \\
\text { bridleways per } \\
\text { hectare }\end{array}$ & Positive & Farm & 2 & Mainly NGOs & Social sustainability & $\begin{array}{l}\text { Niche concern; potential } \\
\text { trade-offs with environmental } \\
\text { and economic sustainability }\end{array}$ \\
\hline $\begin{array}{l}\text { Number of } \\
\text { ponds }\end{array}$ & Positive & Landscape & 2 & NGOs & Environmental sustainability & Niche concern \\
\hline $\begin{array}{l}\text { Presence of } \\
\text { ancient } \\
\text { monuments }\end{array}$ & Positive & Farm & 1 & NGO & Social sustainability & $\begin{array}{l}\text { Niche concern; potential } \\
\text { trade-offs with environmental } \\
\text { and economic sustainability }\end{array}$ \\
\hline
\end{tabular}

of SI (Foresight, 2011; Garnett et al., 2013; Godfray, 2015; Gunton et al., 2016; Rockström et al., 2016; Royal Society, 2009) consider this as a key goal of SI and this would suggest it is an outcome, rather than a system property. However, this indicator lacked specificity, making it difficult to definitively place it within a particular sub-system. Ostrom's SES framework places productivity in the Resource System (Basurto et al., 2013; Ostrom, 2009; Ostrom and Cox, 2010) thus we have done likewise. This lack of specificity could lead to multiple interpretations, adding to the confusion surrounding SI. To be useful, this indicator would need to be more specific in terms of how and what type of productivity was being measured (e.g., labour, land etc.).

'Area of land under agricultural production' was considered as negative for SI. This reflects concerns surrounding the conversion of 'natural' ecosystems into agricultural land (Rockström et al., 2009). The need to halt agricultural expansion has been mentioned as a key goal of SI (Foresight, 2011; Royal Society, 2009). Thus, this indicator is plausible for environmental sustainability, if the 'spared' land is used for conservation, as has been recommended in the literature on 'land sparing' (Hulme et al., 2013; Phalan et al., 2011, 2014). However, the land sparing approach have been criticised for its productivist framing (Fischer et al., 2014) and for dividing the 'ecological' and the 'social' worlds too sharply (Fischer et al., 2014, 2008). There have also been questions raised as to the governance mechanisms required to ensure this 'spared' land is used only for the conservation of biodiversity, rather than converted back into agricultural land at a later date (Fischer et al., 2014).

A confusion is evident in the way the interviewees expected the production and conservation imperatives implied within SI to be implemented. 'Area of land under agricultural production' was considered to be a negative indicator. A reduction in the area under production, without a resultant reduction in total production, would signal that agriculture is becoming more intensive, with the implication that the extra space could be used for conservation purposes. However, the interviewees also suggested 'Area of high nature value farmland' as a positive indicator, which could be seen as contradicting the previous indicator, suggesting that production and conservation would occur in the same space.

Further tensions could be seen around 'Farm size'. Some interviewees (e.g. farmers and food retailers) considered it positive based on the argument that larger farms can achieve economies of scale. Those (mostly from NGOs) who suggested farm size as negative pointed to the importance of smaller, family farms for social sustainability. Evidence suggests that small farms support a larger number of employees per 
unit area than larger farms (Perry, 2017; Winter and Lobley, 2016), suggesting that the loss of these farms would increase rural unemployment (Davidova and Bailey, 2014). Smaller farms can also provide important scenic attributes (Davidova and Bailey, 2014). Nevertheless, over the past century a greater number of the UK's small farms have been lost compared to larger holdings (Winter and Lobley, 2016). The global literature indicates that small farms are more resource-efficient and sustainable than larger farms (Altieri et al., 2012; Altieri and Toledo, 2011; Hazell et al., 2010; Rosset et al., 2011). It would appear, therefore, that if SI favoured larger farms, this would create trade-offs with the social, and potentially environmental, sustainability of rural regions.

Concerns surrounding the use of water in agriculture is manifest in 'Area under irrigated land'. Irrigation can create negative externalities, e.g., desertification (Danfeng et al., 2006; Romm, 2011; Singh, 2009), salinization (George et al., 1997; Kotb et al., 2000; Rozema and Flowers, 2008), and groundwater depletion (Pingali, 2012; Rodell et al., 2009; Zeigler and Mohanty, 2010). Thus, this indicator could be considered as counter to environmental sustainability. Nevertheless, irrigation can be more sustainable, depending on the technology and water source used, e.g., the use of drip irrigation (Ayars et al., 1999). Thus, this indicator would need to be more specific in terms of the technologies and water sources used in order for it to be meaningful.

'Area of high nature value farmland' and 'Degree of habitat connectivity' were suggested at the national and landscape scales, respectively. This suggests that although SI would have to be enacted by individuals on the farm scale, the environmental impact of these actions would need to be considered cumulatively. It also suggests the need for farmer cooperation in order for individual actions to have an aggregate impact. Some have suggested that farmer cooperation for biodiversity conservation is hindered by the current incarnation of the EU CAP (Leventon et al., 2017).

'Length of hedgerows per hectare' and 'Number of ponds' were mentioned in relation to landscape features lost during the intensification of UK agriculture. Both hedgerows and ponds have been accorded a biodiversity action plan in recognition of the importance and vulnerability of these features (UK Biodiversity Action Plan, 2008). Traditionally, hedgerows and other field boundaries have had important agricultural functions, e.g., delineation of land ownership, corralling and providing shelter for livestock (Marshall and Moonen, 2002; Marshall, 2004). However, many have been removed (Marshall and Moonen, 2002). Although hedges have been implicated as sources of weeds and pests, they may still play a role in achieving sustainable agriculture, e.g., in controlling soil erosion control and acting as habitats for beneficial insects (Marshall, 2004). Furthermore, they have an ecological role, providing refuge for biodiversity and as buffers to agrochemical drift (Carey et al., 2008; Marshall, 2004; Ucar and Hall, 2001) and may be important in providing habitats for game species (Carey et al., 2008; Marshall and Moonen, 2002; Marshall, 2004). The number of rural ponds in the UK has fallen over the past 150 years (Wood et al., 2013) and the species richness of these ponds has decreased (Carey et al., 2008). Networks of rural ponds have multiple benefits, e.g., as a component of flood mitigation strategies, and as an alternative to groundwater abstraction for irrigation (Biggs, 2007; Sayer et al., 2013; Wood et al., 2013). Thus, both rural ponds and hedges can be relevant to the sustainability of agriculture in the UK.

'Length of footpaths and bridleways per hectare' and 'Presence of ancient monuments' are manifestations of the social dimensions of SI, but were niche concerns. Although a body of literature exists on the valuation of cultural ecosystem services (Daniel et al., 2012; Hernández-Morcillo et al., 2013; Soini and Birkeland, 2014; van Berkel and Verburg, 2014), little has been done to integrate these dimensions into mainstream ecosystem services assessments (Rey Benayas et al.,
2009; van Berkel and Verburg, 2014). It may be because ecosystem services assessments focus on the economic valuation of such services (Daniel et al., 2012) the normative nature of cultural services and the non-material benefits they provide make quantification difficult (van Berkel and Verburg, 2014). However, these dimensions are well discussed within the literature on sustainable rural tourism (Choi and Sirakaya, 2006; Lee and Hsieh, 2016; Pérez et al., 2013), suggesting importance to economic sustainability. Nevertheless, there may be trade-offs. E.g., legislation in Germany prevents the afforestation of certain landscapes if the cultural value of the scenery is damaged (Schaich et al., 2010). This could limit options for farmers to plant trees to sequester carbon, or to practice agroforestry techniques, potentially impacting on environmental and economic sustainability. Thus, although both indicators have implications for multiple dimensions of sustainability, the benefits may not be equally shared and would require careful thought about potential trade-offs.

\subsection{Resource units}

Fifteen 'Resource Units' indicators were identified, nine of which were mentioned by three or more interviewees (Table 3). Several related to soil properties. 'Soil organic matter' (SOM) was the most frequently suggested and was considered positive for SI. Worldwide, a consequence of intensive agriculture has been a serious decline in SOM (Bellamy et al., 2005; Lal, 2004a; Lal et al., 2007). 'Soil compaction' meanwhile is exacerbated by the use of heavy agricultural machinery (Batey, 2009; Smith et al., 2016; Tim Chamen et al., 2015). These indicators therefore are vital for the productivity and environmental sustainability of agricultural systems.

'Diversity of soil biota', was mentioned by three interviewees. Soil biota is highly complex and poorly understood (de Vries and Bardgett, 2015). However, it is important in delivering soil related ecosystem services (Stockdale and Watson, 2012). Evidence suggest that a 1\% loss of soil biota leads to a $20 \%$ decline in agricultural yields (de Vries and Bardgett, 2015; Graves et al., 2015). This was suggested for the farm-scale, perhaps because soil biota is highly influenced by farm management practices (Stockdale and Watson, 2012). 'Number of earthworms per meter squared' was related to the previous indicator. Thus, these indicators have implications for economic and environmental sustainability.

The indicator 'Farmland bird numbers' was considered a positive indicator at multiple scales. This is a well-established biodiversity indicator for agricultural regions in Europe (Game and Wildlife Conservation Trust, 2017), in recognition of the continued loss of farmland bird numbers (Donald et al., 2001; Inger et al., 2015). This may be a reason why this indicator was mentioned by a relatively large number of the interviewees. However, questions arise as to whether biodiversity conservation would lead to trade-offs with the intensification and economic sustainability of agriculture.

'Number of pollinators per hectare' was suggested by $25 \%$ of the interviewees. Insects are responsible for pollinating around $80 \%$ of British plants (Ollerton et al., 2014; Parliamentary Office of Science and Technology, 2010) and seventy different food crops in the UK (Mwebaze et al., 2010; Pretty et al., 2000). The loss of these services would cost the UK $£ 440$ million a year (Breeze et al., 2011; Parliamentary Office of Science and Technology, 2010). Globally, approximately $35 \%$ of all food production is dependent on insect pollination (Klein et al., 2007). There is, therefore, a strong economic case for conserving pollinators. However, they are under threat (Mwebaze et al., 2010; Ollerton et al., 2014; Parliamentary Office of Science and Technology, 2010). An example of this concern is the debate surrounding the impact of neonicotinoids on pollinators and the associated impact of banning these substances on the financial viability of 
Table 3

SI indicators suggested within the 'Resource Units' sub-system.

\begin{tabular}{|c|c|c|c|c|c|c|}
\hline Indicator name & $\begin{array}{l}\text { Positive or } \\
\text { Negative }\end{array}$ & Scale(s) & $\begin{array}{l}\text { No. } \\
\text { Interviewees }\end{array}$ & $\begin{array}{l}\text { Stakeholder } \\
\text { group(s) }\end{array}$ & $\begin{array}{l}\text { Plausibility re: } \\
\text { sustainability }\end{array}$ & Potential trade-offs and issues \\
\hline Soil organic matter & Positive & $\begin{array}{l}\text { Farm, } \\
\text { national }\end{array}$ & 13 & $\begin{array}{l}\text { NGOs, farmers, } \\
\text { government } \\
\text { organisation and } \\
\text { academics }\end{array}$ & $\begin{array}{l}\text { Economic and } \\
\text { environmental } \\
\text { sustainability }\end{array}$ & \\
\hline $\begin{array}{l}\text { Farmland bird } \\
\text { numbers }\end{array}$ & Positive & $\begin{array}{l}\text { Farm, } \\
\text { landscape, } \\
\text { national }\end{array}$ & 11 & $\begin{array}{l}\text { Mainly NGOs, } \\
\text { academics }\end{array}$ & $\begin{array}{l}\text { Environmental and } \\
\text { social sustainability }\end{array}$ & $\begin{array}{l}\text { Potential trade-offs with } \\
\text { economic sustainability }\end{array}$ \\
\hline $\begin{array}{l}\text { Number of } \\
\text { pollinators per } \\
\text { hectare }\end{array}$ & Positive & $\begin{array}{l}\text { Farm, } \\
\text { landscape }\end{array}$ & 8 & $\begin{array}{l}\text { Mainly NGOs, and } \\
\text { academics }\end{array}$ & $\begin{array}{l}\text { Economic and } \\
\text { environmental } \\
\text { sustainability }\end{array}$ & $\begin{array}{l}\text { Potential trade-offs with } \\
\text { economic sustainability }\end{array}$ \\
\hline $\begin{array}{l}\text { Number of } \\
\text { livestock units per } \\
\text { hectare }\end{array}$ & $\begin{array}{l}\text { Positive, } \\
\text { Negative }\end{array}$ & Farm & 6 & $\begin{array}{l}\text { Mainly NGOs, } \\
\text { farmers, food } \\
\text { retailers }\end{array}$ & $\begin{array}{l}\text { May be relevant for } \\
\text { economic viability }\end{array}$ & $\begin{array}{l}\text { Increased number may have } \\
\text { potential trade-offs with } \\
\text { environmental sustainability } \\
\text { and animal welfare }\end{array}$ \\
\hline Soil compaction & Positive & $\begin{array}{l}\text { Farm, } \\
\text { national }\end{array}$ & 6 & $\begin{array}{l}\text { Mainly farmers and } \\
\text { NGOs }\end{array}$ & $\begin{array}{l}\text { Economic and } \\
\text { environmental } \\
\text { sustainability }\end{array}$ & \\
\hline $\begin{array}{l}\text { Diversity of soil } \\
\text { biota }\end{array}$ & Positive & Farm & 3 & $\begin{array}{l}\text { Academia, input } \\
\text { supplier, NGO }\end{array}$ & $\begin{array}{l}\text { Economic and } \\
\text { environmental } \\
\text { sustainability }\end{array}$ & $\begin{array}{l}\text { Highly influenced by farm } \\
\text { management practices }\end{array}$ \\
\hline $\begin{array}{l}\text { Time taken for } \\
\text { livestock to reach } \\
\text { maturity }\end{array}$ & Negative & Unassigned & 3 & $\begin{array}{l}\text { NGOs and } \\
\text { academics }\end{array}$ & $\begin{array}{l}\text { May be relevant for } \\
\text { economic viability }\end{array}$ & $\begin{array}{l}\text { Potential trade-offs with } \\
\text { animal welfare }\end{array}$ \\
\hline $\begin{array}{l}\text { Incidents of } \\
\text { livestock disease }\end{array}$ & Negative & Unassigned & 3 & NGOs & $\begin{array}{l}\text { Economic viability } \\
\text { of farms }\end{array}$ & $\begin{array}{l}\text { Unsure of scale of } \\
\text { measurement }\end{array}$ \\
\hline Diversity of crops & Positive & National & 3 & Academia, NGOs & $\begin{array}{l}\text { Economic and } \\
\text { environmental } \\
\text { sustainability }\end{array}$ & $\begin{array}{l}\text { Potential trade-offs with } \\
\text { economic viability }\end{array}$ \\
\hline $\begin{array}{l}\text { Depth of water } \\
\text { table }\end{array}$ & Positive & Landscape & 2 & NGO, academia & $\begin{array}{l}\text { Environmental } \\
\text { sustainability }\end{array}$ & Niche concern \\
\hline $\begin{array}{l}\text { Incidents of } \\
\text { antibiotic resistant } \\
\text { livestock diseases }\end{array}$ & Negative & Unassigned & 2 & NGOs & $\begin{array}{l}\text { Economic } \\
\text { sustainability of } \\
\text { farms }\end{array}$ & $\begin{array}{l}\text { Niche concern; scale of } \\
\text { measurement uncertain }\end{array}$ \\
\hline $\begin{array}{l}\text { Number of } \\
\text { offspring produced } \\
\text { per animal per } \\
\text { year }\end{array}$ & Positive & Farm & 2 & Academic, NGO & $\begin{array}{l}\text { Economic } \\
\text { sustainability }\end{array}$ & $\begin{array}{l}\text { Niche concern; } \\
\text { potential trade-offs with } \\
\text { animal welfare }\end{array}$ \\
\hline $\begin{array}{l}\text { Number of } \\
\text { earthworms per } \\
\text { metre squared }\end{array}$ & Positive & Farm & 2 & Farmer, NGO & $\begin{array}{l}\text { Economic and } \\
\text { environmental } \\
\text { sustainability }\end{array}$ & Niche concern \\
\hline $\begin{array}{l}\text { Incidents of } \\
\text { herbicide resistant } \\
\text { weeds }\end{array}$ & Negative & National & 2 & NGO, farmer & $\begin{array}{l}\text { Economic } \\
\text { sustainability }\end{array}$ & Niche concern \\
\hline $\begin{array}{l}\text { Livestock mortality } \\
\text { rates }\end{array}$ & Negative & Unassigned & 1 & NGO & Animal welfare & $\begin{array}{l}\text { Niche concern; Uncertainty } \\
\text { about scale of measurement }\end{array}$ \\
\hline
\end{tabular}

European agriculture (Campbell, 2013; Eisenstein, 2015; Godfray et al., 2014; Gross, 2013). Thus, this indicator is pertinent to the economic and environmental sustainability of agriculture.

A number of indicators were related to livestock productivity and resource use efficiency. 'Number of livestock units per hectare' was suggested both as a positive and negative indicator, indicating a lack of consensus among the interviewees. If positive (i.e. increased number per ha), then a higher stocking density might increase yields, but could raise ethical and environmental concerns (Bilotta et al., 2007; Lemaire et al., 2014). Conversely, if negative (i.e. extensive, outdoor systems) a reduced number of livestock may affect economic sustainability, but may be better from an ethical and environmental standpoint. Other indicators - including 'Livestock mortality rates', 'Time taken for livestock to reach maturity', and 'Number of offspring produced per animal per year' - indicate an interest in higher productivity. These would make economic sense, and are areas of interest to on-going livestock breeding programmes (Burgess and Morris, 2009). Nevertheless, breeding livestock for the production of a single commodity and the increasing use of newly emerging reproductive technologies may lead to trade-offs with animal welfare (Pickett, 2010). However, selective breeding may lead to increased livestock welfare, e.g., selecting for traits in poultry to reduce inclination to cannibalism (Burgess and Morris, 2009).

'Incidents of antibiotic resistant livestock diseases' was related to the above concerns and is linked to the over-use of antibiotics in agriculture. Globally, antibiotics are commonly used as prophylactic treatments and as growth enhancers in high-density, housed livestock systems (O'Neill Commission, 2016), which have been promoted for resource-use efficiency and high yields (Godfray, 2015; Murgueitio, 1990; Tilman et al., 2002). However, antibiotic use has been linked to the emergence of antibiotic resistant pathogens (Cogliani et al., 2011; Garnett and Godfray, 2012; Hughes et al., 2008; Pretty et al., 2000). It is therefore understandable that this indicator was seen as negative. Related to this was 'Incidents of herbicide resistant weeds', which was also a negative indicator. The interviewees specifically mentioned the arable weed black-grass, Alopecurus myosuroides, which is a significant herbicide-resistant weed species in Europe (Moss et al., 2007). This weed can lead to significant yield losses (Moss, 2013), impacting the productivity and economic viability of agriculture. 
The indicator 'Crop diversity' concerned agrobiodiversity, key to the continued sustainability of agricultural systems (Hoisington et al., 1999; Veteto, 2008). This indicator reflects a desire to remedy the impacts of crop monocultures, e.g. the loss of traditional cultivars (Foresight, 2011; Godfray et al., 2010; Grando and McGee, 1990; Pasam et al., 2014). Traditional cultivars provide many cultural values as well (Mahon et al., 2016). However, concerns about the loss of agrobiodiversity are widespread (Frison et al., 2011). Therefore, the indicator 'Crop diversity' can be seen as relevant to all three sustainability attributes (economic, environmental and social) of agriculture.

'Depth of water table' was suggested as a positive, landscape scale indicator. This is related to the negative impacts of irrigation, e.g., declining depths of water tables (Pingali, 2012; Rodell et al., 2009; Zeigler and Mohanty, 2010), salinization of arable lands, scarcities of drinking water, and desertification. Moreover, there are concerns about the future availability of water due to the impacts of climate change and the growing domestic and industrial demands (Pond et al., 2007; Water UK, 2016). Therefore, this indicator is crucial for the viability of agriculture.

\subsection{Governance}

Altogether, five 'Governance' indicators were identified, although only two were mentioned by more than three interviewees (Table 4). 'Presence of subsidies to encourage more environmentally sensitive farming' was most frequently suggested. Farmer subsidies have been key policy instruments to encourage environmentally sustainable farming in Europe (Dobbs and Pretty, 2008; Kleijn and Sutherland, 2003; Swetnam et al., 2004). However, there are controversies surrounding the effectiveness of these mechanisms (Dobbs and Pretty, 2004; Leventon et al., 2017). On a local scale, they have been implicated in distorting land prices, preventing marginal lands, which may be better used for conservation, from being taken out of production (Merckx and Pereira, 2015) and for failing to promote farmer collaboration (Leventon et al., 2017). Moreover, although subsidised agri-environmental schemes have been found to be effective at protecting existing biodiversity in extensively farmed areas, it does little in terms of adding biodiversity to intensively farmed areas (Batáry et al., 2015; Dobbs and Pretty, 2008; Kleijn and Sutherland, 2003). Nevertheless, some argue that the removal of subsidies could lead to greater negative externalities, e.g., increased farm amalgamation and greater pesticide use (Pretty et al., 2000). Environmental subsidies have also been identified as obstacles to innovations as they create perverse incentives for some farmers and discourage the uptake of highly productive and resource efficient technologies (Rosegrant, 2003). Furthermore, the use of subsidies by developed countries are seen by some as protectionist measures that distort trade and negatively affect less developed regions (Merckx and Pereira, 2015; Wise, 2004).

'Farmers' perception of their relationship with landlord' and 'Number of short-term farm tenancies' were niche concerns surrounding issues of tenant farming. Although studies in Scotland (Myers et al., 2014), and England and Wales (Ilbery et al., 2010) found farmer-landlord relationships to be largely positive, there were challenges concerning tenant farmers' ability to diversify their operations, with $30 \%$ of the surveyed farmers stating that their landlords were unsupportive (Maye et al., 2009). An interviewee expressed a similar concern, stating,

“... people who rent land on an annual basis or a short term tenancy - so three to five years - they are quite sort of nervous of putting too much improvement into that land to get better efficiencies out of the animals because of at the end of the year that land could be taken away from them and the investment they have put into it would be gone..." (Interview 9)

These findings are relevant to SI, which may require the investment in and use of novel technologies (Foresight, 2011; Royal Society, 2009). Thus, although 'Farmers' perception of their relationship with landlord' may not be a pressing issue, the indicator 'Number of short-term farm tenancies' would appear to be much more relevant.

'Presence of animal welfare standards' is a context-specific concern, as its interpretation is dependent on cultural norms (Szúcs et al., 2012; Vanhonacker et al., 2008). Nevertheless, it is one of the most contentious issues relating to SI (Garnett et al., 2013) and may be of increasing importance as novel technologies are promoted (Godfray, 2015; Pickett, 2010). This indicator relates to the ethical dimensions of sustainability, which some (Burford et al., 2013) view as the 'missing' pillar of sustainability. Animal welfare is increasingly seen as vital for the competitiveness and profitability of food industries due to shifting consumer attitudes (Carlsson et al., 2007; Napolitano et al., 2010; Tonsor et al., 2009).

'Ability of farmers to negotiate fair prices for what they produce' was mentioned in relation to farmers' relationships with supermarkets.

Table 4

SI indicators suggested within the 'Governance' sub-system.

\begin{tabular}{|c|c|c|c|c|c|c|}
\hline Indicator name & $\begin{array}{l}\text { Positive or } \\
\text { Negative }\end{array}$ & Scale(s) & $\begin{array}{l}\text { No. } \\
\text { Interviewees }\end{array}$ & $\begin{array}{l}\text { Stakeholder } \\
\text { group(s) }\end{array}$ & $\begin{array}{l}\text { Plausibility re: } \\
\text { sustainability }\end{array}$ & $\begin{array}{l}\text { Potential trade-offs and } \\
\text { issues }\end{array}$ \\
\hline $\begin{array}{l}\text { Presence of subsidies to } \\
\text { encourage more } \\
\text { environmentally } \\
\text { sensitive farming }\end{array}$ & Positive & National & 7 & $\begin{array}{l}\text { Mainly NGOs - } \\
\text { agricultural and } \\
\text { conservation }\end{array}$ & $\begin{array}{l}\text { Environmental } \\
\text { sustainability }\end{array}$ & $\begin{array}{l}\text { Potential trade-offs with } \\
\text { productivity and } \\
\text { efficiency; impacts on } \\
\text { farmers in developing } \\
\text { countries }\end{array}$ \\
\hline $\begin{array}{l}\text { Number of short-term } \\
\text { farm tenancies }(3-5 \\
\text { years) }\end{array}$ & Negative & Unassigned & 3 & $\begin{array}{l}\text { Levy board, } \\
\text { farmer, } \\
\text { government } \\
\text { organisation }\end{array}$ & $\begin{array}{l}\text { Environmental, social } \\
\text { and economic } \\
\text { sustainability }\end{array}$ & $\begin{array}{l}\text { Unsure of scale of } \\
\text { measurement }\end{array}$ \\
\hline $\begin{array}{l}\text { Farmers' perception of } \\
\text { their relationship with } \\
\text { landlord }\end{array}$ & Unassigned & Unassigned & 1 & $\begin{array}{l}\text { Government } \\
\text { organisation }\end{array}$ & $\begin{array}{l}\text { Environmental, } \\
\text { economic and social } \\
\text { sustainability }\end{array}$ & Niche concern \\
\hline $\begin{array}{l}\text { Presence of animal } \\
\text { welfare standards }\end{array}$ & Positive & National & 1 & Academia & $\begin{array}{l}\text { Ethical/moral aspect of } \\
\text { sustainability, also } \\
\text { potentially economic } \\
\text { sustainability }\end{array}$ & $\begin{array}{l}\text { Potential trade-offs with } \\
\text { intensification; niche } \\
\text { concern; } \\
\text { Highly context specific }\end{array}$ \\
\hline $\begin{array}{l}\text { Ability of farmers to } \\
\text { negotiate fair prices for } \\
\text { what they produce }\end{array}$ & Positive & Unassigned & 1 & $\begin{array}{l}\text { NGO } \\
\text { (conservation) }\end{array}$ & Economic sustainability & Niche concern \\
\hline
\end{tabular}


Consumer choices are increasingly mediated by a small number of large supermarket chains (Angus et al., 2009; Renwick et al., 2012). In the UK the four largest chains control over $50 \%$ of the market share of food and non-alcoholic drinks (DEFRA, 2016) and exhibit an increasingly oligopolistic structure (Burt and Sparks, 2003; Fearne et al., 2005), acting as gateways between producers and consumers (Fair Trade Advocacy Office, 2014; Fearne et al., 2005; Hingley, 2005). Supermarkets are now developing exclusive relationships with a decreasing number of producers (Fair Trade Advocacy Office, 2014; Hingley, 2005; Burt and Sparks, 2003), creating greater opportunities for supermarkets to exercise their power unfairly (Burt and Sparks, 2003; Hingley, 2005). This may deprive farmers of their due prices, reducing the economic and social sustainability of agriculture.

\subsection{Resource users}

In total, 22 indicators were identified relating to the 'Resource Users', ten of those indicators were mentioned by more than three interviewees (Table 5). The interviewees suggested several economic attributes necessary for SI. However, the majority of these were infrequently mentioned.

'Age of farmers' was considered to be a negative indicator for the national level. An interviewee stated,

“... you've got this massively aging farming population where you've got older people going out and they haven't got sons or daughters to carry it on - and I mean what happens to those farms - they just get eaten up by larger neighbouring farms who just want land ... so then the scope for small producers to get going is just completely limited..." (Interview 20)

This is an important factor for the vitality of farming. Younger farmers are more willing to undertake training, adopt novel technologies and have more interest in the environment (DEFRA, 2013a; Ingram and Kirwan, 2011; Lobley, 2010). However, agriculture in developed nations is not attracting enough young people due, in part, to its perceived low status (Angus et al., 2009; Ingram and Kirwan, 2011; Lobley, 2010). In 2013 in the UK, approximately one third of farm holders were aged over 65 years (DEFRA, 2015; Department for Environment, Food and Rural Affairs et al., 2016). This situation is unlikely to change in the near future, as the majority of elderly UK farmers are reluctant to retire (DEFRA, 2013b; Ingram and Kirwan, 2011). The present incarnation of the CAP Single Farm Payment, UK inheritance tax framework, high start-up costs, and increasing land prices have all been implicated (DEFRA, 2013a; Ingram and Kirwan, 2011). This restricts opportunities for new entrants in the industry (DEFRA, 2013a). 'Presence of a farm succession plan' was a related concern, in that it can be a route to reducing the average age of farmers (Ingram and Kirwan, 2011; Lobley, 2010). Succession is also an indicator of the likely future direction of a farm business (Burton and Walford, 2005; Chiswell, 2014). Farms without a successor are less likely to be diversified, are less intensively managed and are more likely to reduce capital investment (Chiswell, 2014; Lobley, 2010). However, succession is dependent on the current farmer wanting to retire, which may be in doubt (Fraser, 2005). If the process has not taken place in an efficient manner the new farmer may be ill-equipped to run the farm, which may threaten the ability of the farm to sustainably intensify (Burton and Walford, 2005; Chiswell, 2014; Lobley, 2010).

'Farmer social networks' was mentioned as a positive, farm scale indicator. One interviewee stated,

"...if your farming in the future is based on individuals working on farms that are very isolated and have very limited social contact so that the social quality of life is very poor that may be less desirable than something where there's much stronger social capital engagement..." (Interview 5)

Increasing mechanization has been implicated in this change, with farmers following more isolated work patterns (Gregoire, 2002). Social isolation is a significant factor impacting on the mental and physical health of farmers (Gregoire, 2002). Farmer social networks play a vital role in the diffusion of knowledge and innovation, e.g., the network of LEAF (Linking Environmental and Farming) demonstration farms. Thus, this has implications for the social and economic sustainability of agriculture. Related to this was 'Size of the national rural population'. The interviewees discussed this in terms of 'Least Favoured Areas' of the UK, where agriculture is less appealing. One interviewee stated,

"... There are environmental issues too in the marginal areas but I think the fundamental problem is keeping people there..." (Interview 6)

All the indicators relating to farmers' attitudes were unassigned in terms of scale and whether they were positive or negative for SI. Risk averse farmers are less likely to adopt novel technologies (Willock et al., 1999b), which could have implications for the implementation of SI (Foresight, 2011; Royal Society, 2009). Furthermore, positive farmer attitudes towards nature, coupled with higher farm incomes, increases the uptake of conservation practices (Willock et al., 1999a). Thus, these indicators have implications for the sustainability of agriculture. However, in order to be useful they would need to be better defined.

'Affordability of rural housing' was a niche concern. This is an area of attention to the UK government, with rural housing in England, on average, more expensive than urban homes (DEFRA, 2013b). The prevalence of holiday homes, the non-replacement of council houses and the significant number of low-income households in rural areas are thought to contribute to this (Shelter et al., 2004). This is of particular concern to agricultural workers and tenant farmers, many of whom live in housing that is tied to their work (Gregoire, 2002), impacting on the social sustainability of rural regions (Shelter et al., 2004).

The interviewees suggested 'Number of people in agricultural employment' and 'Casualization of employment in agriculture' in relation to employment in agriculture. The former was suggested as both positive and negative, whereas the later was unassigned. These could be seen as counter to the previously mentioned indicator 'Extent of farm mechanisation'. Many interviewees voiced the concern that agriculture had become increasingly intensive, through mechanisation, at the expense of agricultural employment. This was also seen as making agriculture less 'social', leading to farmer loneliness and making the sector less attractive to new entrants. The 'Casualization of employment in agriculture' could reduce job security, leading to potential social issues, such as greater unhappiness and isolation.

The indicator 'Number of native language speakers' was considered to be a positive indicator for the national level. It was felt that the agricultural industry in the UK was one of the last strongholds of traditional cultural knowledge, e.g., the native Welsh language, thus important to cultural and social sustainability. Globally, linguistic diversity is being lost at a rapid rate (Whaley, 2003). Increased globalisation and development which prioritises the maximisation of economic output have been implicated in this (Reyes-García et al., 2013; Woodley et al., 2006).

\subsection{Interactions}

In total, 21 indicators were identified in the 'Interactions' sub-system, 12 were mentioned by more than three interviewees (Table 6). Three related to the volume of external inputs used in agriculture and all were assigned as negative for SI. The need for agricultural sys- 
Table 5

SI indicators suggested within the 'Resource Users' sub-system.

\begin{tabular}{|c|c|c|c|c|c|c|}
\hline Indicator name & $\begin{array}{l}\text { Positive or } \\
\text { Negative }\end{array}$ & Scale(s) & $\begin{array}{l}\text { No. } \\
\text { Interviewees }\end{array}$ & Stakeholder group(s) & $\begin{array}{l}\text { Plausibility re: } \\
\text { sustainability }\end{array}$ & $\begin{array}{l}\text { Potential trade-offs and } \\
\text { issues }\end{array}$ \\
\hline $\begin{array}{l}\text { Number of people } \\
\text { in agricultural } \\
\text { employment }\end{array}$ & $\begin{array}{l}\text { Positive, } \\
\text { Negative }\end{array}$ & National & 8 & $\begin{array}{l}\text { Mainly NGOS and } \\
\text { farmers }\end{array}$ & Social sustainability & $\begin{array}{l}\text { Potential trade-offs } \\
\text { with intensification and } \\
\text { economic sustainability }\end{array}$ \\
\hline $\begin{array}{l}\text { Educational level of } \\
\text { famers }\end{array}$ & Positive & $\begin{array}{l}\text { Farm, } \\
\text { national }\end{array}$ & 7 & $\begin{array}{l}\text { Mainly input suppliers, } \\
\text { academics and } \\
\text { agriculture NGOs }\end{array}$ & $\begin{array}{l}\text { Economic, } \\
\text { environmental and } \\
\text { social sustainability }\end{array}$ & \\
\hline $\begin{array}{l}\text { Age of farm } \\
\text { infrastructure }\end{array}$ & Negative & $\begin{array}{l}\text { Farm, } \\
\text { national }\end{array}$ & 5 & $\begin{array}{l}\text { NGOs - agriculture } \\
\text { and conservation, levy } \\
\text { board, Government } \\
\text { organisation }\end{array}$ & Economic sustainability & \\
\hline Age of farmers & Negative & National & 5 & $\begin{array}{l}\text { Mainly input suppliers } \\
\text { and agriculture NGOs }\end{array}$ & $\begin{array}{l}\text { Social sustainability, } \\
\text { possibly environmental } \\
\text { and economic } \\
\text { sustainability }\end{array}$ & \\
\hline $\begin{array}{l}\text { Presence of farm } \\
\text { income from non- } \\
\text { agricultural } \\
\text { activities }\end{array}$ & Positive & Farm & 5 & $\begin{array}{l}\text { Mainly academia, } \\
\text { agricultural NGOs and } \\
\text { farmers }\end{array}$ & Economic sustainability & \\
\hline $\begin{array}{l}\text { Total income from } \\
\text { subsidies }\end{array}$ & Negative & $\begin{array}{l}\text { Farm, } \\
\text { national }\end{array}$ & 5 & $\begin{array}{l}\text { Mainly agricultural } \\
\text { NGOs and farmers }\end{array}$ & $\begin{array}{l}\text { Potentially economic } \\
\text { sustainability }\end{array}$ & \\
\hline $\begin{array}{l}\text { Amount of financial } \\
\text { capital invested in } \\
\text { farm }\end{array}$ & Positive & Farm & 4 & $\begin{array}{l}\text { Government } \\
\text { organisation, levy } \\
\text { board, agriculture } \\
\text { NGO }\end{array}$ & & $\begin{array}{l}\text { Would need to be } \\
\text { better defined - what is } \\
\text { the financial capital } \\
\text { invested in? }\end{array}$ \\
\hline $\begin{array}{l}\text { Size of the national } \\
\text { rural population }\end{array}$ & Positive & National & 3 & NGOs and farmers & Social sustainability & \\
\hline $\begin{array}{l}\text { Farmer social } \\
\text { networks }\end{array}$ & Positive & Farm & 3 & Academia & Social sustainability & \\
\hline $\begin{array}{l}\text { Farmer access to } \\
\text { multiple sources of } \\
\text { information }\end{array}$ & Positive & Unassigned & 3 & $\begin{array}{l}\text { Agriculture and } \\
\text { conservation NGOs }\end{array}$ & & $\begin{array}{l}\text { Would need to be } \\
\text { better defined - what } \\
\text { information are farmers } \\
\text { receiving? } \\
\text { Unsure of scale of } \\
\text { measurement }\end{array}$ \\
\hline $\begin{array}{l}\text { Casualization of } \\
\text { employment in } \\
\text { agriculture }\end{array}$ & Unassigned & $\begin{array}{l}\text { Farm, } \\
\text { national }\end{array}$ & 2 & Academics & Economic sustainability & $\begin{array}{l}\text { Trade-off with social } \\
\text { sustainability }\end{array}$ \\
\hline $\begin{array}{l}\text { Farmer financial } \\
\text { savings }\end{array}$ & Positive & Farm & 2 & $\begin{array}{l}\text { Government } \\
\text { organisation, } \\
\text { conservation NGO }\end{array}$ & Economic sustainability & Niche concern \\
\hline $\begin{array}{l}\text { Presence of farm } \\
\text { income from off- } \\
\text { farm employment }\end{array}$ & Positive & Farm & 2 & $\begin{array}{l}\text { Academia agricultural } \\
\text { NGO }\end{array}$ & Economic sustainability & Niche concern \\
\hline $\begin{array}{l}\text { Number of native } \\
\text { language speakers }\end{array}$ & Positive & National & 1 & $\begin{array}{l}\text { Agricultural levy } \\
\text { board }\end{array}$ & Social sustainability & Niche concern \\
\hline $\begin{array}{l}\text { Affordability of } \\
\text { rural housing }\end{array}$ & Positive & National & 1 & Agricultural NGO & Social sustainability & Niche concern \\
\hline $\begin{array}{l}\text { Farmers' attitudes } \\
\text { towards debt }\end{array}$ & Unassigned & Unassigned & 1 & Academia & Economic sustainability & Niche concern \\
\hline $\begin{array}{l}\text { Farmers' attitudes } \\
\text { towards farm } \\
\text { succession }\end{array}$ & Unassigned & Unassigned & 1 & Academia & $\begin{array}{l}\text { Economic, social and } \\
\text { environmental } \\
\text { sustainability }\end{array}$ & $\begin{array}{l}\text { Niche concern; Unsure } \\
\text { of scale of } \\
\text { measurement }\end{array}$ \\
\hline $\begin{array}{l}\text { Farmers' attitudes } \\
\text { towards farming } \\
\text { and agriculture }\end{array}$ & Unassigned & Unassigned & 1 & Academia & $\begin{array}{l}\text { Economic, social and } \\
\text { environmental } \\
\text { sustainability }\end{array}$ & $\begin{array}{l}\text { Niche concern; Unsure } \\
\text { of scale of } \\
\text { measurement }\end{array}$ \\
\hline $\begin{array}{l}\text { Farmers' attitudes } \\
\text { towards nature }\end{array}$ & Unassigned & Unassigned & 1 & Academia & $\begin{array}{l}\text { Environmental } \\
\text { sustainability }\end{array}$ & $\begin{array}{l}\text { Niche concern; Unsure } \\
\text { of scale of } \\
\text { measurement }\end{array}$ \\
\hline $\begin{array}{l}\text { Farmers' attitudes } \\
\text { towards technology }\end{array}$ & Unassigned & Unassigned & 1 & Academia & Economic sustainability & $\begin{array}{l}\text { Niche concern; Unsure } \\
\text { of scale of } \\
\text { measurement }\end{array}$ \\
\hline $\begin{array}{l}\text { Farmers' attitudes } \\
\text { towards their peers }\end{array}$ & Unassigned & Unassigned & 1 & Academia & Social sustainability & $\begin{array}{l}\text { Niche concern; Unsure } \\
\text { of scale of } \\
\text { measurement }\end{array}$ \\
\hline $\begin{array}{l}\text { Presence of a farm } \\
\text { succession plan }\end{array}$ & Positive & Unassigned & 1 & Academia & $\begin{array}{l}\text { Social sustainability; } \\
\text { potentially for economic } \\
\text { and environmental } \\
\text { sustainability }\end{array}$ & $\begin{array}{l}\text { Niche concern; Unsure } \\
\text { of scale of } \\
\text { measurement }\end{array}$ \\
\hline
\end{tabular}


Table 6

SI indicators suggested within the 'Interactions' sub-system.

\begin{tabular}{|c|c|c|c|c|c|c|}
\hline Indicator name & $\begin{array}{l}\text { Positive or } \\
\text { Negative }\end{array}$ & Scale(s) & $\begin{array}{l}\text { No. } \\
\text { Interviewees }\end{array}$ & Stakeholder group(s) & $\begin{array}{l}\text { Plausibility re: } \\
\text { sustainability }\end{array}$ & $\begin{array}{l}\text { Potential trade-offs and } \\
\text { issues }\end{array}$ \\
\hline $\begin{array}{l}\text { Quantity of } \\
\text { fertilizers used per } \\
\text { hectare }\end{array}$ & Negative & Farm & 11 & $\begin{array}{l}\text { Mainly, NGOs - } \\
\text { agriculture, } \\
\text { conservation, } \\
\text { academia, food } \\
\text { retailers }\end{array}$ & $\begin{array}{l}\text { Environmental } \\
\text { sustainability; } \\
\text { Potentially economic } \\
\text { sustainability }\end{array}$ & \\
\hline $\begin{array}{l}\text { Extent of farm } \\
\text { mechanisation }\end{array}$ & Positive & $\begin{array}{l}\text { Farm, } \\
\text { national }\end{array}$ & 11 & $\begin{array}{l}\text { Mainly food retailers, } \\
\text { academia, } \\
\text { government } \\
\text { organisation, } \\
\text { agricultural NGOs }\end{array}$ & $\begin{array}{l}\text { Economic } \\
\text { sustainability }\end{array}$ & $\begin{array}{l}\text { Potential trade-offs with } \\
\text { social sustainability } \\
\text { (agricultural employment) }\end{array}$ \\
\hline $\begin{array}{l}\text { Quantity of crop } \\
\text { protection } \\
\text { chemicals applied } \\
\text { per hectare }\end{array}$ & Negative & Farm & 10 & $\begin{array}{l}\text { Mainly NGOS - } \\
\text { conservation, } \\
\text { sustainability and } \\
\text { agriculture }\end{array}$ & $\begin{array}{l}\text { Environmental } \\
\text { sustainability; } \\
\text { Potentially economic } \\
\text { sustainability }\end{array}$ & \\
\hline $\begin{array}{l}\text { Presence of } \\
\text { collaborative } \\
\text { networks of farmers }\end{array}$ & Positive & Landscape & 10 & $\begin{array}{l}\text { Mainly agricultural } \\
\text { NGOs }\end{array}$ & Social sustainability & $\begin{array}{l}\text { Would be dependent on } \\
\text { what the farmers are } \\
\text { collaborating on }\end{array}$ \\
\hline $\begin{array}{l}\text { Use of crop } \\
\text { rotations }\end{array}$ & Positive & Farm & 5 & $\begin{array}{l}\text { Mainly NGOs- } \\
\text { agriculture and } \\
\text { conservation }\end{array}$ & $\begin{array}{l}\text { Environmental } \\
\text { sustainability }\end{array}$ & $\begin{array}{l}\text { Trade-off with economic } \\
\text { sustainability }\end{array}$ \\
\hline $\begin{array}{l}\text { Presence of } \\
\text { interactions } \\
\text { between farmers } \\
\text { and researchers }\end{array}$ & Positive & Unassigned & 4 & $\begin{array}{l}\text { Mainly agricultural } \\
\text { NGOs }\end{array}$ & & $\begin{array}{l}\text { Would depend on what the } \\
\text { groups are collaborating on; } \\
\text { Unsure of scale of } \\
\text { measurement }\end{array}$ \\
\hline $\begin{array}{l}\text { Quantity of energy } \\
\text { used per farm }\end{array}$ & Negative & Farm & 4 & $\begin{array}{l}\text { Academia, input } \\
\text { supplier, animal } \\
\text { welfare NGO }\end{array}$ & $\begin{array}{l}\text { Environmental } \\
\text { sustainability; } \\
\text { Potentially economic } \\
\text { sustainability }\end{array}$ & $\begin{array}{l}\text { Trade-off with economic } \\
\text { sustainability if reduction in } \\
\text { energy use reduces yields }\end{array}$ \\
\hline $\begin{array}{l}\text { Number of public } \\
\text { engagement } \\
\text { activities held per } \\
\text { year }\end{array}$ & Positive & Farm & 3 & $\begin{array}{l}\text { Academia, } \\
\text { agricultural NGO, } \\
\text { input supplier }\end{array}$ & Social sustainability & \\
\hline $\begin{array}{l}\text { Number of tillage } \\
\text { operations }\end{array}$ & Negative & Farm & 3 & $\begin{array}{l}\text { Farmer, academia, } \\
\text { agriculture NGO }\end{array}$ & $\begin{array}{l}\text { Environmental } \\
\text { sustainability }\end{array}$ & $\begin{array}{l}\text { Trade-off with economic } \\
\text { sustainability if reduction in } \\
\text { energy use reduces yields }\end{array}$ \\
\hline $\begin{array}{l}\text { Use of grain as } \\
\text { animal feed }\end{array}$ & Negative & Unassigned & 3 & $\begin{array}{l}\text { Mainly agriculture } \\
\text { NGOs }\end{array}$ & $\begin{array}{l}\text { Environmental } \\
\text { sustainability }\end{array}$ & $\begin{array}{l}\text { Potential trade-offs with } \\
\text { economic sustainability if } \\
\text { yields are reduced; } \\
\text { Unsure of scale of } \\
\text { measurement }\end{array}$ \\
\hline Use of monocultures & Negative & $\begin{array}{l}\text { Farm, } \\
\text { landscape }\end{array}$ & 3 & $\begin{array}{l}\text { Farmer, conservation } \\
\text { NGOs }\end{array}$ & $\begin{array}{l}\text { Environmental } \\
\text { sustainability }\end{array}$ & $\begin{array}{l}\text { Potential trade-offs with } \\
\text { economic sustainability if } \\
\text { yields are reduced }\end{array}$ \\
\hline $\begin{array}{l}\text { Use of genetically } \\
\text { modified crops }\end{array}$ & $\begin{array}{l}\text { Positive, } \\
\text { negative }\end{array}$ & Unassigned & 3 & $\begin{array}{l}\text { Agricultural NGOs } \\
\text { and input suppliers }\end{array}$ & $\begin{array}{l}\text { Economic and also } \\
\text { potentially } \\
\text { environmental } \\
\text { sustainability }\end{array}$ & $\begin{array}{l}\text { Potential trade-offs with } \\
\text { social and ethical } \\
\text { sustainability }\end{array}$ \\
\hline $\begin{array}{l}\text { Number of retailers } \\
\text { to which each farm } \\
\text { supplies its produce }\end{array}$ & Unassigned & Landscape & 2 & $\begin{array}{l}\text { Academia, } \\
\text { agricultural NGO }\end{array}$ & & $\begin{array}{l}\text { Niche concern; Would need } \\
\text { to be better defined in order } \\
\text { to be meaningful }\end{array}$ \\
\hline $\begin{array}{l}\text { Use of management } \\
\text { practices for } \\
\text { waterway } \\
\text { conservation }\end{array}$ & Positive & Landscape & 2 & $\begin{array}{l}\text { Mainly agriculture } \\
\text { NGOs }\end{array}$ & $\begin{array}{l}\text { Environmental } \\
\text { sustainability }\end{array}$ & $\begin{array}{l}\text { Niche concern; potential } \\
\text { trade-offs with economic } \\
\text { sustainability if yields are } \\
\text { reduced }\end{array}$ \\
\hline $\begin{array}{l}\text { Quantity of } \\
\text { renewable energy } \\
\text { used per farm }\end{array}$ & Positive & Farm & 2 & Agriculture NGOs & $\begin{array}{l}\text { Environmental } \\
\text { sustainability; } \\
\text { Potentially economic } \\
\text { sustainability }\end{array}$ & Niche concern \\
\hline $\begin{array}{l}\text { Use of agroforestry } \\
\text { techniques }\end{array}$ & Positive & Unassigned & 2 & $\begin{array}{l}\text { NGOs - agriculture, } \\
\text { animal welfare }\end{array}$ & $\begin{array}{l}\text { Environmental } \\
\text { sustainability }\end{array}$ & $\begin{array}{l}\text { Niche concern; Potential } \\
\text { trade-offs with economic } \\
\text { sustainability if yields are } \\
\text { reduced; Unsure of scale of } \\
\text { measurement }\end{array}$ \\
\hline $\begin{array}{l}\text { Use of grass as } \\
\text { animal feed }\end{array}$ & Positive & Unassigned & 2 & $\begin{array}{l}\text { Mainly agriculture } \\
\text { NGOs }\end{array}$ & $\begin{array}{l}\text { Environmental } \\
\text { sustainability }\end{array}$ & $\begin{array}{l}\text { Niche concern; Unsure of } \\
\text { scale of measurement; } \\
\text { Potential trade-offs with } \\
\text { economic sustainability if } \\
\text { yields are reduced }\end{array}$ \\
\hline
\end{tabular}


Table 6 (Continued)

\begin{tabular}{|c|c|c|c|c|c|c|}
\hline Indicator name & $\begin{array}{l}\text { Positive or } \\
\text { Negative }\end{array}$ & Scale(s) & $\begin{array}{l}\text { No. } \\
\text { Interviewees }\end{array}$ & Stakeholder group(s) & $\begin{array}{l}\text { Plausibility re: } \\
\text { sustainability }\end{array}$ & $\begin{array}{l}\text { Potential trade-offs and } \\
\text { issues }\end{array}$ \\
\hline $\begin{array}{l}\text { Use of organic } \\
\text { manure }\end{array}$ & Positive & Unassigned & 2 & $\begin{array}{l}\text { Farmer, agriculture } \\
\text { NGO }\end{array}$ & $\begin{array}{l}\text { Environmental } \\
\text { sustainability }\end{array}$ & $\begin{array}{l}\text { Niche concern; Potential } \\
\text { trade-offs with economic }\end{array}$ \\
\hline $\begin{array}{l}\text { Use of 'precision } \\
\text { agriculture' } \\
\text { techniques }\end{array}$ & Positive & Farm & 2 & $\begin{array}{l}\text { Academic, agriculture } \\
\text { NGO }\end{array}$ & $\begin{array}{l}\text { Environmental } \\
\text { sustainability }\end{array}$ & Niche concern \\
\hline $\begin{array}{l}\text { Use of housed } \\
\text { livestock systems }\end{array}$ & Unassigned & Unassigned & 1 & Animal welfare NGO & $\begin{array}{l}\text { Social sustainability } \\
\text { - however this is } \\
\text { debated }\end{array}$ & $\begin{array}{l}\text { Niche concern; Potential } \\
\text { trade-offs with } \\
\text { intensification (if negative); } \\
\text { Unsure of scale of } \\
\text { measurement }\end{array}$ \\
\hline $\begin{array}{l}\text { Use of loss-leader } \\
\text { pricing of food by } \\
\text { supermarkets }\end{array}$ & Negative & Unassigned & 1 & Input supplier & & $\begin{array}{l}\text { Trade-off with economic } \\
\text { sustainability; } \\
\text { Niche concern; Unsure of } \\
\text { scale of measurement }\end{array}$ \\
\hline
\end{tabular}

tems to reduce the use of externally-derived inputs is a key aim of SI (e.g. Pretty, 1997). The environmental impacts of the intensive use of external inputs are well documented (Bechmann, 2005; Dungait et al., 2012; Neal et al., 2006; de Vries and Bardgett, 2015; Graves et al., 2015; Ollerton et al., 2014). Externalities are not just borne by farmers, but also the wider society (Pretty et al., 2000). Therefore, these indicators are highly germane for environmental and social sustainability.

The indicator 'Extent of farm mechanisation' was assigned to the farm and national scales. This may be germane for intensification, however, there may be trade-offs, e.g. between intensification and social sustainability dimensions - such as farmer happiness and levels of rural employment -discussed in detail in Section 3.4 (Gregoire, 2002).

'Presence of collaborative networks of farmers', was suggested as a positive indicator at the landscape scale. Related to this was the 'Presence of interactions between farmers and research', suggested as a positive indicator but without any scale assigned. As discussed previously (Section 3.4), farmer-to-farmer and farmer-to-researcher interactions are vital for improving the economic, environmental and social sustainability of agriculture (Braun and Duveskog, 2011).

The interviewees mentioned 'Quantity of renewable energy used per farm', 'Use of grass as animal feed', and 'Use of organic manure' in relation to renewable inputs. Each was suggested as positive. Indicators related to regenerative agricultural practices included the 'Use of management practices for waterway conservation', the 'Use of agroforestry techniques', the 'Use of crop rotations' (which was contrasted with 'Use of monocultures'), and the 'Use of precision agriculture techniques'. All were considered to be positive, but mentioned at a variety of scales, e.g., 'Use of management practices for waterway conservation' was assigned to the landscape scale. This is plausible since water-courses are rarely confined to one agricultural holding. The importance of taking a catchment scale approach is well acknowledged (DEFRA, 2013c) and evidence suggests that this approach is successful (CSF Evidence Team, 2014). These indicators suggest that the interviewees envisage SI as not only causing less environmental damage (Elliott et al., 2013; Foresight, 2011; Royal Society, 2009), but also benefiting the environment (Elliott et al., 2013).

'Use of grass as animal feed' was mentioned in contrast to 'Use of grain as animal feed'. The former was considered positive, the later negative. These relate to the debates concerning the role of livestock farming in feeding an increasing global population (Garnett et al., 2013; Garnett and Godfray, 2012; Godfray et al., 2010; Godfray, 2015). Arguments exist, especially in the Third Sector, that grains used for live- stock feed could be better utilised as human food (Lewis-Brown and Lymberry, 2012).

The indicator 'Use of housed livestock systems' was unassigned regarding its positive or negative orientation and scale of measurement. This is a controversial issue in the UK and has attracted considerable coverage in the British press (Wasley, 2015; Wasley et al., 2017; Wedderburn, 2017). There have been debates around the value of 'mega-dairies'. While the advocates mention the economic benefits, opponents mention the welfare costs. It would seem therefore that trade-offs between the dimensions of sustainability would need to be considered in this respect.

The indicator 'Number of tillage operations' was suggested as a negative indicator at the farm scale. This relates to the adverse impact of tillage on soil erosion, soil biota, and Greenhouse Gas emissions (Prasuhn, 2012). It has been demonstrated that it is possible to reduce the number of tillage operations without a corresponding loss of yield (Prasuhn, 2012) and low-tillage and no-tillage practices have gained ground globally (Busari et al., 2015; Holland, 2004; Pittelkow et al., 2015). This suggests that, as an indicator, 'Number of tillage operations' reflects a desire to increase the environmental sustainability of agriculture, without a trade-off with yields - a key aim of SI.

'Use of genetically modified crops' was assigned as both positive and negative. In terms of scale, it was unassigned, perhaps because this technology is not currently used in the UK (DEFRA et al., 2015). Some have suggested that GM technologies have the potential to improve the environmental and economic sustainability of agriculture. China has been able to substantially reduce its use of chemical pesticides via the use of pest-resistant GM cotton varieties (Conway and Toenniessen, 1999; Raney, 2006). However, there are concerns that the new genes added to GM crops might escape via pollen to nearby weed species or other un-modified plants, potentially disrupting the environment (Conway, 2000). Furthermore, there are concerns about the impact of GM technologies on social and ethical sustainability. The expansion of intellectual property rights surrounding seed development has made it possible for companies to appropriate seed saving activities, reducing farmer independence (Mascarenhas and Busch, 2006). In addition, there are concerns that a small number of transnational agribusinesses are taking control of the world's supply of food, resulting in huge numbers of farmers dependent these companies for their livelihoods, threatening their economic sustainability (Conway, 2000; Strauss, 2009). This trend is unlikely to result in equitable sharing of benefits from advances in biotechnology, and is beginning to generate public fears in 
some countries that GM technology only benefits commercial interests (Conway, 2000; Godfray et al., 2010).

'Number of retailers to which each farm supplies its produce' was suggested for the landscape scale, but was unassigned as to whether it was positive or negative. The interviewees mentioned this in relation to the business relationships between farmers and large food retailers, discussed further in Section 3.3. It is likely that both the number of suppliers a farmer has business relationships with and the 'fairness' of these relationships (Burt and Sparks, 2003; Duffy et al., 2003; Fair Trade Advocacy Office, 2014; Friends of the Earth, 2003; Heijden and Vink, 2013; Seely, 2012) impacts sustainability (Fearne et al., 2005; Hingley, 2005). Thus, this indicator would need to be more specific in order to be a meaningful. Related to this is 'Use of loss-leader pricing of food by supermarkets', which was unassigned according to scale, and considered as negative for SI, which again relates to the business relationships between farmers and retailers.

'Number of public engagement activities held per year' was considered to be a positive, farm scale indicator and relates to social sustainability. An example is the annual 'Open Farm Sunday' events in the UK (Linking Environment and Farming, 2017). A lack of public knowledge about farming has been implicated in the tensions between farmers and the public (Wachenheim and Rathge, 2000). Such tensions could mean that the agricultural sector does not have the public and political support to adapt to emerging challenges (Worsley et al., 2015). A survey of visitors to farms as part of 'Open Farm Sunday' found that respondents felt that their understanding of the multifunctionality of agriculture had increased and that they were more likely to purchase British produce and food labelled with animal welfare and environmental certification after the visit (Hine and Pretty, 2008). Therefore, this indicator has implications for multiple dimensions of sustainability.

\subsection{Outcomes}

Altogether, 20 indicators were suggested as relating to 'Outcomes', with 17 mentioned by more than three interviewees (Table 7). 'Yield' was the most commonly suggested and considered to be positive for the farm and national scales. Increased yield is widely seen as a key justification for SI (Foresight, 2011; Pretty et al., 2010, 2011; Royal Society, 2009; World Bank et al., 2013). It is seen as a way to feed a growing world population (Foresight, 2011; Pretty et al., 2010; Royal Society, 2009; World Bank et al., 2013), a tool to raise the incomes of rural inhabitants and critical to avoid more land having to be converted to agriculture (Royal Society, 2009; World Bank et al., 2013). However, it is controversial. Some have placed doubts on the true extent of future increases in demand for food (Hunter et al., 2017), while others argue that the cause of hunger is unequal distribution, rather than lack of production (Sen, 1981). Raising yields without considering other aspects of agriculture can undermine the environmental and social sustainability of agriculture, as for example, was noticed during the Green Revolution (Hewitt de Alcantara, 1976; Pingali, 2012; Rodell et al., 2009; Sangha, 2013; Zeigler and Mohanty, 2010).

'Farmer income' was suggested as a positive indicator for multiple scales. Adequate income is the key for farmers to access new technologies, undertake better management of the farm for environmental outcomes, and become more productive (Chikowo et al., 2014). Insufficient farmer income has implications for the social sustainability of agriculture as well (Dillon et al., 2014). However, farm income in many countries (Department of Agriculture and Rural Development, 2016; Renting et al., 2003), is declining. Thus, farmer income is particularly pertinent.

Agriculture is a significant contributor to global 'Greenhouse gas (GHG) emissions' (Johnson et al., 2007). Net GHG emissions from agri- culture continues to increase, due to demand for livestock products and the energy demand from the increased use of irrigation and agrochemicals (Pachauri et al., 2015; Smith et al., 2007; Tubiello et al., 2014). A key justification for the need for SI has been to prevent the expansion of agriculture into 'natural' ecosystems, in part, to limit the GHG emissions caused by the conversion of wetlands and forests (Foley et al., 2011; Tilman et al., 2011). As such, this indicator is pertinent to environmental sustainability (Campbell et al., 2014; Royal Society, 2009; World Bank et al., 2013). Nevertheless, it is possible that some of the strategies may result in trade-offs, e.g., reducing the use of externally derived inputs may reduce yields and impact on economic sustainability (Smith et al., 2008).

Five indicators were suggested relating to agricultural pollution: 'Concentration of crop protection chemicals in waterways', 'Concentration of fertilizer run-off in waterways', 'Concentration of slurry run-off in waterways', 'Concentration of soil particulates in waterways', and 'Particulate matter in the air'. These are well-known environmental externalities and are therefore crucial for environmental sustainability (Campbell et al., 2014; Royal Society, 2009; World Bank et al., 2013).

The interviewees suggested four indicators related to resource use efficiency and intensity: 'Energy use efficiency', 'Fertilizer use efficiency', 'Agricultural land use intensity', and 'Water use efficiency'. One interviewee mentioned resource use efficiency as key to realising SI,

To me it means making better use of the resources we've got - so it's sort of - trying to increase our outputs, but doing that by increasing perhaps the efficiency of which we use the resources we've got - so making better use of water, better use of nitrogen..." (Interview 11)

Given worldwide decline in resources, e.g., per capita lands and freshwater (Rockström et al., 2009, 2016), issues of efficiency seems plausible. Enhancing resource use efficiency has been mentioned by some (Barnes and Thomson, 2014; Petersen and Snapp, 2015; Rockström et al., 2016; Struik et al., 2014) as a key aim of SI. However, others (Food Ethics Council (Great Britain), 2012) have questioned whether this fully embraces the concept of sustainability (Godfray, 2015), whether increasing the efficiency of resource-use can be sustained into the long-term without impacting yields (Struik et al., 2014), or whether other strategies, such as a reduction in post-consumer waste, could be more effective at ensuring the global population is fed (Aschemann-Witzel et al., 2015; Parfitt et al., 2010).

'Top soil loss (tonnes per hectare per year)' was mentioned by $25 \%$ of the interviewees as a negative indicator at the national, landscape, and farm scales. The importance of and the threats facing agricultural soil resources have been discussed previously (Sections 3.2 and 3.5). Approximately $1 \%$ of the world's top soil is lost each year due to erosion caused by unsustainable farming practices (Horrigan et al., 2002) causing a significant financial loss (Graves et al., 2015). Thus, this is germane to both environmental and economic sustainability.

'Volume of waste produced on farm' was suggested as a negative, farm scale indicator. Agricultural waste is a well-known threat to environmental, economic, and social sustainability (Aschemann-Witzel et al., 2015; Godfray et al., 2010; Parfitt et al., 2010). However, the interviewees focused on on-farm waste, whilst the bulk of the SI literature from developed countries like the UK (Food Ethics Council (Great Britain), 2012; Garnett and Godfray, 2012) refers to 'post-consumer', rather than 'post-harvest' waste (Godfray et al., 2010).

'Amount of carbon sequestered on farm' was viewed as a positive indicator for the farm level. The loss of soil organic matter from agricultural soils, due to intensive agricultural practices has contributed to 
Table 7

SI indicators suggested within the 'Outcomes' sub-system.

\begin{tabular}{|c|c|c|c|c|c|c|}
\hline Indicator name & $\begin{array}{l}\text { Positive } \\
\text { or } \\
\text { Negative }\end{array}$ & Scale(s) & $\begin{array}{l}\text { No. } \\
\text { Interviewees }\end{array}$ & $\begin{array}{l}\text { Stakeholder } \\
\text { group(s) }\end{array}$ & $\begin{array}{l}\text { Plausibility re: } \\
\text { sustainability }\end{array}$ & Potential trade-offs and issues \\
\hline Yield & Positive & $\begin{array}{l}\text { Farm, } \\
\text { national }\end{array}$ & 22 & $\begin{array}{l}\text { All stakeholder } \\
\text { groups }\end{array}$ & $\begin{array}{l}\text { Economic } \\
\text { sustainability }\end{array}$ & $\begin{array}{l}\text { Potential trade-offs with } \\
\text { environmental and social } \\
\text { sustainability }\end{array}$ \\
\hline Farmer income & Positive & $\begin{array}{l}\text { Farm, } \\
\text { national, } \\
\text { global }\end{array}$ & 17 & $\begin{array}{l}\text { Mainly NGOs - } \\
\text { conservation, } \\
\text { agriculture, } \\
\text { academics and } \\
\text { farmers }\end{array}$ & $\begin{array}{l}\text { Economic } \\
\text { sustainability }\end{array}$ & $\begin{array}{l}\text { Narrow focus could lead to } \\
\text { potential trade-offs with } \\
\text { environmental sustainability }\end{array}$ \\
\hline $\begin{array}{l}\text { Greenhouse Gas } \\
\text { emissions }\end{array}$ & Negative & $\begin{array}{l}\text { Farm, } \\
\text { national }\end{array}$ & 14 & $\begin{array}{l}\text { All stakeholder } \\
\text { groups }\end{array}$ & $\begin{array}{l}\text { Environmental } \\
\text { sustainability }\end{array}$ & $\begin{array}{l}\text { Potential trade-offs with economic } \\
\text { and social sustainability if yields } \\
\text { are reduced }\end{array}$ \\
\hline $\begin{array}{l}\text { Concentration of } \\
\text { fertilizer run-off in } \\
\text { waterways }\end{array}$ & Negative & $\begin{array}{l}\text { Landscape, } \\
\text { national }\end{array}$ & 10 & $\begin{array}{l}\text { Mainly NGOs, } \\
\text { academics, } \\
\text { government } \\
\text { organisations, food } \\
\text { retailers }\end{array}$ & $\begin{array}{l}\text { Environmental } \\
\text { sustainability }\end{array}$ & $\begin{array}{l}\text { Potential trade-offs with economic } \\
\text { sustainability if yields are reduced }\end{array}$ \\
\hline $\begin{array}{l}\text { Water use } \\
\text { efficiency }\end{array}$ & Positive & Farm & 9 & $\begin{array}{l}\text { Mainly farmers, } \\
\text { academics, NGOs - } \\
\text { agriculture, } \\
\text { conservation }\end{array}$ & $\begin{array}{l}\text { Environmental } \\
\text { sustainability }\end{array}$ & $\begin{array}{l}\text { Unsure whether trends in } \\
\text { increasing resource use efficiency } \\
\text { can be maintained without } \\
\text { impacting yields }\end{array}$ \\
\hline $\begin{array}{l}\text { Volume of waste } \\
\text { produced on farm }\end{array}$ & Negative & Farm & 9 & $\begin{array}{l}\text { Mainly NGOs and } \\
\text { farmers }\end{array}$ & $\begin{array}{l}\text { Environmental } \\
\text { sustainability }\end{array}$ & \\
\hline $\begin{array}{l}\text { Top soil loss } \\
\text { (tonnes per hectare } \\
\text { per year) }\end{array}$ & Negative & $\begin{array}{l}\text { Farm, } \\
\text { landscape, } \\
\text { national }\end{array}$ & 8 & $\begin{array}{l}\text { Mainly academics, } \\
\text { NGOs and farmers }\end{array}$ & $\begin{array}{l}\text { Environmental and } \\
\text { economic } \\
\text { sustainability }\end{array}$ & \\
\hline $\begin{array}{l}\text { Energy use } \\
\text { efficiency }\end{array}$ & Positive & Farm & 8 & $\begin{array}{l}\text { Mainly academics, } \\
\text { agriculture NGOs }\end{array}$ & $\begin{array}{l}\text { Environmental and } \\
\text { economic } \\
\text { sustainability }\end{array}$ & $\begin{array}{l}\text { Unsure whether trends in } \\
\text { increasing resource use efficiency } \\
\text { can be maintained without } \\
\text { impacting yields }\end{array}$ \\
\hline Cost of production & Negative & Farm & 7 & $\begin{array}{l}\text { Mainly farmers, } \\
\text { food retailers, } \\
\text { advisory service } \\
\text { providers }\end{array}$ & $\begin{array}{l}\text { Economic } \\
\text { sustainability }\end{array}$ & \\
\hline $\begin{array}{l}\text { Fertilizer use } \\
\text { efficiency }\end{array}$ & Positive & Farm & 7 & $\begin{array}{l}\text { Mainly agriculture } \\
\text { NGOs and farmers }\end{array}$ & $\begin{array}{l}\text { Environmental and } \\
\text { economic } \\
\text { sustainability }\end{array}$ & $\begin{array}{l}\text { Potential trade-offs with economic } \\
\text { sustainability if yields are } \\
\text { reduced; Unsure whether trends } \\
\text { in increasing resource use } \\
\text { efficiency can be maintained } \\
\text { without impacting yields }\end{array}$ \\
\hline $\begin{array}{l}\text { Concentration of } \\
\text { crop protection } \\
\text { chemicals in } \\
\text { waterways }\end{array}$ & Negative & $\begin{array}{l}\text { Landscape, } \\
\text { national }\end{array}$ & 6 & $\begin{array}{l}\text { Mainly NGOs and } \\
\text { academics }\end{array}$ & $\begin{array}{l}\text { Environmental } \\
\text { sustainability }\end{array}$ & $\begin{array}{l}\text { Potential trade-offs with economic } \\
\text { sustainability if yields are reduced }\end{array}$ \\
\hline $\begin{array}{l}\text { Concentration of } \\
\text { soil particulates in } \\
\text { waterways }\end{array}$ & Negative & Landscape & 6 & $\begin{array}{l}\text { Mainly NGOs and } \\
\text { academics }\end{array}$ & $\begin{array}{l}\text { Environmental } \\
\text { sustainability }\end{array}$ & $\begin{array}{l}\text { Potential trade-offs with economic } \\
\text { sustainability if yields are reduced }\end{array}$ \\
\hline $\begin{array}{l}\text { Agricultural land } \\
\text { use intensity }\end{array}$ & Positive & $\begin{array}{l}\text { Farm, } \\
\text { national }\end{array}$ & 6 & $\begin{array}{l}\text { Mainly agriculture } \\
\text { NGOs, input } \\
\text { suppliers and } \\
\text { academics }\end{array}$ & $\begin{array}{l}\text { Economic } \\
\text { sustainability }\end{array}$ & $\begin{array}{l}\text { Potential trade-offs with } \\
\text { environmental sustainability }\end{array}$ \\
\hline $\begin{array}{l}\text { Amount of carbon } \\
\text { sequestered on } \\
\text { farm }\end{array}$ & Positive & Farm & 5 & $\begin{array}{l}\text { Mainly academics } \\
\text { and NGOs }\end{array}$ & $\begin{array}{l}\text { Environmental } \\
\text { sustainability }\end{array}$ & $\begin{array}{l}\text { Potential trade-offs with economic } \\
\text { sustainability if yields are reduced }\end{array}$ \\
\hline $\begin{array}{l}\text { Concentration of } \\
\text { slurry run-off in } \\
\text { waterways }\end{array}$ & Negative & Landscape & 4 & $\begin{array}{l}\text { Academics and } \\
\text { NGOs }\end{array}$ & $\begin{array}{l}\text { Environmental } \\
\text { sustainability }\end{array}$ & $\begin{array}{l}\text { Potential trade-offs with economic } \\
\text { sustainability if yields are reduced }\end{array}$ \\
\hline $\begin{array}{l}\text { Farm worker } \\
\text { happiness }\end{array}$ & Positive & Farm & 3 & $\begin{array}{l}\text { NGO animal } \\
\text { welfare, input } \\
\text { supplier, academic }\end{array}$ & $\begin{array}{l}\text { Social } \\
\text { sustainability }\end{array}$ & \\
\hline $\begin{array}{l}\text { Incidents of } \\
\text { pesticides in food }\end{array}$ & Negative & National & 3 & $\begin{array}{l}\text { Academia, NGOs - } \\
\text { sustainability, } \\
\text { conservation }\end{array}$ & $\begin{array}{l}\text { Social } \\
\text { sustainability }\end{array}$ & \\
\hline $\begin{array}{l}\text { Number of visitors } \\
\text { to a farm }\end{array}$ & Positive & Farm & 2 & NGOs and farmers & $\begin{array}{l}\text { Social and possibly } \\
\text { also economic } \\
\text { sustainability }\end{array}$ & Niche concern \\
\hline $\begin{array}{l}\text { Amount of } \\
\text { renewable energy } \\
\text { generated on farm }\end{array}$ & Positive & Farm & 1 & Agriculture NGO & $\begin{array}{l}\text { Environmental and } \\
\text { possibly economic } \\
\text { sustainability }\end{array}$ & $\begin{array}{l}\text { Niche concern; Greater detail is } \\
\text { needed - how is the energy } \\
\text { generated? }\end{array}$ \\
\hline
\end{tabular}




\begin{tabular}{|c|c|c|c|c|c|c|}
\hline Indicator name & $\begin{array}{l}\text { Positive } \\
\text { or } \\
\text { Negative }\end{array}$ & Scale(s) & $\begin{array}{l}\text { No. } \\
\text { Interviewees }\end{array}$ & $\begin{array}{l}\text { Stakeholder } \\
\text { group(s) }\end{array}$ & $\begin{array}{l}\text { Plausibility re: } \\
\text { sustainability }\end{array}$ & Potential trade-offs and issues \\
\hline $\begin{array}{l}\text { Particulate matter } \\
\text { in the air }\end{array}$ & Negative & Unassigned & 1 & Academia & $\begin{array}{l}\text { Environmental } \\
\text { sustainability }\end{array}$ & $\begin{array}{l}\text { Niche concern; Unsure of scale of } \\
\text { measurement }\end{array}$ \\
\hline
\end{tabular}

anthropogenic climate change, via the release of carbon stored in soils. This has also reduced soil fertility and achievable yields (Lal, 2004b; Lal et al., 2007). A variety of regenerative agricultural practices have been advanced in order to halt, or reverse this process, sequester carbon, and maintain yields (Hutchinson et al., 2007; Johnson et al., 2007; Lal, 2004b, 2004a; Lal et al., 2007). Thus, this indicator impacts the environmental and economic sustainability of agriculture.

'Farm worker happiness' was suggested by $9.4 \%$ of the interviewees. Traditionally, farmers have been satisfied with farming as a job and a way of life, due to unconstrained decision making, pleasant work surroundings, and the intellectual challenge of their work (Willock et al., 1999b). However, contemporary farming has given way to increasing levels of stress, depression, and negativity (Fraser, 2005), due to financial worries, volatile commodity prices, increasing time pressures, bureaucratic interference, and farmer isolation (Fraser, 2005; Gregoire, 2002; Willock et al., 1999b). The happiness of farm workers, especially seasonal workers, is impacted by poor quality housing, falling wages, lack of benefits such as sick pay, and the unpredictable availability of work (Fraser, 2005; Gregoire, 2002). Consequently, in terms of occupational groups, farmers make up the largest number of suicides in the UK (Gregoire, 2002). Thus, this indicator is crucial for the social sustainability of agriculture.

The indicator 'Number of visitors to a farm' was mentioned as a positive, farm scale indicator and is related to the indicator 'Number of public engagement activities held per year' discussed in Section 3.5. As such, this indicator has implications for the social and economic sustainability of agriculture.

'Amount of renewable energy generated on farm' was considered to be positive for SI. On-farm renewable energy (OFRE) projects are seen as a key route towards achieving SI in the UK and the multifunctionality of agriculture (Mbzibain et al., 2013). Nevertheless, there are issues surrounding certain types of OFRE projects, e.g. the cultivation of biofuel crops (Lovett et al., 2009). It is also argued that energy crop cultivation could reduce land available for food production undermining food security (Tenenbaum, 2008). Energy crops could also undermine the aesthetic quality of certain landscapes (Lovett et al., 2009). Thus, in order to be meaningful, this indicator needs to consider how the OFRE is produced.

\subsection{Environment}

In total, 17 indicators were identified in relation to the 'Environment' sub-system, seven were mentioned by more than three interviewees (Table 8). Several indicators related to factor market trends: 'Farmer access to credit', 'Trends in agricultural output prices', 'Trends in agricultural input prices', and 'Trends in land prices'. The first two were considered as positive, the latter two as negative. Land prices are a particular issue in the UK (Angus et al., 2009), limiting opportunities for farmers to expand their enterprises and creating significant barriers for new entrants (Angus et al., 2009). In less economically developed regions, the high prices of agrochemicals and hybrid seed varieties often limit achievable yields, perpetuating food insecurity and exacerbating poverty. In these contexts, access to credit can allow farmers to purchase necessary inputs (Dorward and Chirwa, 2011), suggesting its importance to economic sustainability.
'Competitiveness of UK agriculture' was seen as positive for SI. The interviewees believed that although the market was a driving force behind agriculture, British agriculture was not as competitive as it could be, impacting on its economic sustainability. The interviewees mentioned that poorly targeted subsidies from the EU prevented farmers from reacting to market forces. One stakeholder stated,

“...The driving force behind UK agriculture is the market - what is the demand for our products - but what actually drives it is the farmers themselves - in terms of how they react to that and I don't necessarily think that we've been that good at reacting to market forces which has been as a result of years of non-market forces focused subsides ..." (Interview 7)

'Frequency of extreme weather events' was suggested as a negative indicator for SI; however, it was unassigned in terms of scale. Extreme weather events are exacerbated by climate change (Powell and Reinhard, 2016) and are predicted to have a net negative impact on global agricultural yields (Powell and Reinhard, 2016), e.g., changing the patterns and distributions of crop pests (Anyamba et al., 2014). These events increase the volatility of food and commodity prices (Anyamba et al., 2014) and impact upon the livelihoods and food security of smallholder farmers (Shannon and Motha, 2015; Swaminathan and Rengalakshmi, 2016). Thus this indicator has relevance for the economic and social sustainability of agriculture.

The interviewees suggested a number of indicators related to consumers: 'Consumer preference for high welfare livestock products', 'Consumer preference for uniform fruits and vegetables', and 'Consumer preference for cheaper food'. All were unassigned according to scale, with the first three considered as negative and the fourth positive. The role of the public was also mentioned in 'Public perception of agriculture', suggested as a positive indicator. SI, as it is currently interpreted, has been criticised by NGOs and others for focusing too tightly on production-based concerns, ignoring the impact that changing consumer demands could have on food availability (Cook et al., 2015; Food Ethics Council (Great Britain), 2012; Garnett and Godfray, 2012; Lewis-Brown and Lymberry, 2012). Thus, these indicators are pertinent to the more holistic interpretation of SI, which would go some way towards addressing some of these concerns.

'The price of food in supermarkets' was mentioned as both negative and positive. In justifying the need to lower food prices an interviewee stated,

"...the affordability of food is just absolutely critical to the whole argument - and this is not just the UK but globally..." (Interview 13)

It is noteworthy that the interviewees stressed the importance of 'affordable' rather than 'cheap' food, the latter being a phrase that could have negative connotations. This is related to other factors. For instance, intensive, housed livestock systems could produce cheaper more plentiful animal protein than extensive, outdoor systems. This suggests a potential trade-off between production-based concerns and ethical concerns (Lewis-Brown and Lymberry, 2012). Some interviewees were concerned about food becoming too cheap and believed 
Table 8

SI indicators suggested within the 'Environment' sub-system.

\begin{tabular}{|c|c|c|c|c|c|c|}
\hline Indicator name & $\begin{array}{l}\text { Positive or } \\
\text { Negative }\end{array}$ & Scale(s) & $\begin{array}{l}\text { No. } \\
\text { Interviewees }\end{array}$ & Stakeholder group(s) & $\begin{array}{l}\text { Plausibility re: } \\
\text { sustainability }\end{array}$ & $\begin{array}{l}\text { Potential trade-offs and } \\
\text { issues }\end{array}$ \\
\hline $\begin{array}{l}\text { Trends in agricultural } \\
\text { output prices }\end{array}$ & Negative & Unassigned & 9 & $\begin{array}{l}\text { Mainly academics } \\
\text { and input suppliers }\end{array}$ & $\begin{array}{l}\text { Economic } \\
\text { sustainability if } \\
\text { output prices aren't } \\
\text { subsequently lowered }\end{array}$ & $\begin{array}{l}\text { Unsure of scale of } \\
\text { measurement, potential } \\
\text { trade-off with social } \\
\text { sustainability if output } \\
\text { prices lower }\end{array}$ \\
\hline $\begin{array}{l}\text { Competitiveness of } \\
\text { UK agriculture }\end{array}$ & Positive & Global & 7 & $\begin{array}{l}\text { Mainly NGOs, } \\
\text { farmers, food } \\
\text { retailers }\end{array}$ & $\begin{array}{l}\text { Economic } \\
\text { sustainability }\end{array}$ & \\
\hline $\begin{array}{l}\text { The price of food in } \\
\text { supermarkets }\end{array}$ & $\begin{array}{l}\text { Negative, } \\
\text { Positive }\end{array}$ & National & 6 & $\begin{array}{l}\text { Mainly farmers, food } \\
\text { retailers, NGOs - } \\
\text { agriculture and } \\
\text { animal welfare }\end{array}$ & Social sustainability & $\begin{array}{l}\text { Potential trade-offs with } \\
\text { environmental } \\
\text { sustainability and livestock } \\
\text { welfare }\end{array}$ \\
\hline $\begin{array}{l}\text { Frequency of extreme } \\
\text { weather events }\end{array}$ & Negative & Unassigned & 5 & $\begin{array}{l}\text { Food retailer, } \\
\text { government } \\
\text { organisation, NGOs, } \\
\text { advisory service } \\
\text { providers }\end{array}$ & & $\begin{array}{l}\text { Unsure of scale of } \\
\text { measurement, negatively } \\
\text { impacts the economic and } \\
\text { social sustainability of } \\
\text { agriculture }\end{array}$ \\
\hline $\begin{array}{l}\text { Public perception of } \\
\text { agriculture }\end{array}$ & Positive & $\begin{array}{l}\text { Landscape, } \\
\text { national }\end{array}$ & 4 & $\begin{array}{l}\text { Farmer, NGO, } \\
\text { academia, input } \\
\text { supplier }\end{array}$ & Social sustainability & \\
\hline $\begin{array}{l}\text { Consumer preference } \\
\text { for cheaper food }\end{array}$ & Negative & Unassigned & 3 & Farmers and NGOs & $\begin{array}{l}\text { Economic } \\
\text { sustainability }\end{array}$ & $\begin{array}{l}\text { Unsure of scale of } \\
\text { measurement }\end{array}$ \\
\hline $\begin{array}{l}\text { Consumer preference } \\
\text { for high welfare } \\
\text { livestock products }\end{array}$ & Positive & Unassigned & 3 & NGOs and academia & Social sustainability & $\begin{array}{l}\text { Unsure of scale of } \\
\text { measurement }\end{array}$ \\
\hline $\begin{array}{l}\text { Monitoring of water } \\
\text { quality by the } \\
\text { Environment Agency }\end{array}$ & Positive & National & 2 & $\begin{array}{l}\text { NGO, advisory } \\
\text { service provider }\end{array}$ & $\begin{array}{l}\text { Environmental } \\
\text { sustainability }\end{array}$ & Niche concern \\
\hline $\begin{array}{l}\text { Presence of national } \\
\text { polices on } \\
\text { biodiversity }\end{array}$ & Positive & National & 2 & NGO, academia & $\begin{array}{l}\text { Environmental } \\
\text { sustainability }\end{array}$ & Niche concern \\
\hline $\begin{array}{l}\text { Presence of } \\
\text { international polices } \\
\text { on climate change }\end{array}$ & Positive & Global & 2 & NGO, academia & $\begin{array}{l}\text { Environmental } \\
\text { sustainability }\end{array}$ & Niche concern \\
\hline Trends in land prices & Negative & Unassigned & 2 & $\begin{array}{l}\text { Input supplier, } \\
\text { farmer }\end{array}$ & & Niche concern \\
\hline $\begin{array}{l}\text { Trends in agricultural } \\
\text { input prices }\end{array}$ & Negative & Global & 2 & $\begin{array}{l}\text { Food retailer and } \\
\text { advisory service } \\
\text { provider }\end{array}$ & & Niche concern \\
\hline $\begin{array}{l}\text { Farmer access to } \\
\text { credit }\end{array}$ & Positive & Unassigned & 2 & $\begin{array}{l}\text { Levy board, } \\
\text { government } \\
\text { organisation }\end{array}$ & $\begin{array}{l}\text { Economic } \\
\text { sustainability }\end{array}$ & $\begin{array}{l}\text { Niche concern; Unsure of } \\
\text { scale of measurement }\end{array}$ \\
\hline $\begin{array}{l}\text { Amount of funding } \\
\text { for agri-research }\end{array}$ & Positive & Unassigned & 1 & $\begin{array}{l}\text { Agricultural levy } \\
\text { board }\end{array}$ & & $\begin{array}{l}\text { Niche concern; Unsure of } \\
\text { scale of measurement }\end{array}$ \\
\hline $\begin{array}{l}\text { Consumer preferences } \\
\text { for uniform fruits and } \\
\text { vegetables }\end{array}$ & Negative & Unassigned & 1 & Farmer & & $\begin{array}{l}\text { Potential trade-off with } \\
\text { economic and } \\
\text { environmental } \\
\text { sustainability; } \\
\text { Niche concern; Unsure of } \\
\text { scale of measurement }\end{array}$ \\
\hline $\begin{array}{l}\text { Presence of national } \\
\text { polices on climate } \\
\text { change }\end{array}$ & Positive & National & 1 & Academia & $\begin{array}{l}\text { Environmental } \\
\text { sustainability }\end{array}$ & Niche concern \\
\hline $\begin{array}{l}\text { Presence of national } \\
\text { polices on water } \\
\text { quality }\end{array}$ & Positive & National & 1 & Academia & $\begin{array}{l}\text { Environmental } \\
\text { sustainability }\end{array}$ & Niche concern \\
\hline
\end{tabular}

that the price of food would need to be considered in conjunction with the negative externalities caused by agriculture.

A number of indicators were suggested in relation to national and international policies. These indicators may have been suggested in recognition of the fact that tackling some large scale challenges, e.g., climate change would require government interventions. This may be because these factors affect the wider society and therefore do not generate private incentives for producers to change their behaviour (Pretty et al., 2000).
'Amount of funding for agri-research' was considered to be positive for SI. Some authors have suggested research and development to be key to achieving SI (Foresight, 2011; Royal Society, 2009). However, the sustainability implications would depend on the direction of the research. For example, the UK government's 'Agritech Strategy' (UK Government, 2017, 2013) funds four 'innovations centres', one of which focuses on facilitating SI in the UK (Agrimetrics, 2017). However, it would appear that these centres are taking a productivist approach, which could impact on sustainability (UK Government, 2013). 


\section{Conclusions and implications}

In this investigation we applied a holistic, systems framework to identify the indicators of SI from the viewpoints of UK stakeholders, evaluate the plausibility of these indicators in terms of commonly accepted principles of sustainability, and identify the critical issues that may arise in their the adoption and operation. The purpose of this paper is not to recommend any particular blueprint of SI, but instead, to raise issues and questions for future dialogue.

The UK stakeholders interviewed suggested a large number (110 in total) of potential SI indicators. All seemed plausible for sustainability, either economic, environmental or social, or a combination of these attributes. These covered the desired outcomes of SI, as well as the processes (interventions) and enabling conditions required to achieve these outcomes. Previously, an 'anything goes' approach to achieving SI has been promoted by some (e.g., Garnett and Godfray, 2012), although this has been criticised by actors in the Third Sector (e.g., Collins and Chandrasekaran, 2012). Our work advances the SI debate, as we have begun to identify some of the practices and enabling conditions needed to achieve SI. Examples of SI practices include, the application of agroforestry techniques, the use of organic manures and precision agriculture techniques. Examples of enabling conditions include, public perception of agriculture, competitiveness of UK agriculture and trends in agricultural output prices. We believe this holistic framework of indicators, underpinned by systems thinking, can be a starting point for future, constructive dialogue. The indicator framework, however, raises several critical issues for further dialogue.

One such issue is that the most frequently suggested indicators skewed towards consideration of the processes, enabling conditions, and outcomes required to increase or maintain agricultural production. Examples of such process indicators included a combination of agroecological practices - such as the 'Use of crop rotations' - and high-tech solutions - such as the 'Use of genetically modified crops'. Examples of the indicators related to enabling conditions included the 'Presence of national polices on biodiversity'. Those related to outcomes included 'Yield' and 'Cost of production'. This resonates with the definition of SI provided by influential actors such as the UK Royal Society and the Foresight report (Foresight, 2011; Royal Society, 2009). Nevertheless, the question remains as to why increased agricultural production is needed in an affluent country, such as the UK, when so much is wasted (Aschemann-Witzel et al., 2015; Parfitt et al., 2010). Is this needed to feed a growing global population? Or, in order to limit global agricultural expansion into 'natural' environments, e.g., tropical rainforests? How will increasing the volume of food produced in the UK achieve these goals?

In addition, the social, and especially the cultural and ethical dimensions, which some (Burford et al., 2013; Soini and Birkeland, 2014) have suggested as an emerging fourth pillar of sustainability, although recognised, were mentioned by only a few stakeholders. For example, the indicators relating to livestock welfare were, for the most part, suggested by the NGO interviewees only. Furthermore, even though agriculture is a powerful cultural force and has played a key role in the development of many traditions and beliefs (OECD, 2009), indicators related to these dimensions of agriculture, e.g., religious customs about the extraction of resources from the environment (Parajuli, 2016), or rules surrounding the agricultural technologies that are permissible (Peterson, 2016), were not mentioned by the participants. Similar deficiencies can be noted relating to gender issues and the need for fair pay both for farmer workers in the UK and those participating in international supply chains. These issues are currently of prominence in the literature on the sustainability of international supply chains (Canfora, 2016; Hutchins and Sutherland, 2008; Kirwan et al., 2017; Kummu et al., 2012) and therefore it is surprising that they were not accorded more prominence in this investigation. In addition, issues of power and governance within agriculture were poorly represented.

This raises a number of questions. Is it appropriate to continue discussing the concept as Sustainable Intensification, when it does not place equal emphasis on all three pillars of sustainability? Organisations such as the $\mathrm{UN},{ }^{1}$ World Bank ${ }^{2}$ and $\mathrm{OECD}^{3}$ all conceptualise sustainability as comprising three equal pillars and yet this is not how the sustainability in SI has been interpreted by the interviewees in this investigation. If this is the case, would it then be more appropriate to rename the concept of SI (Godfray, 2015) potentially as 'Ecological Intensification', as has been suggested by some (Struik et al., 2014; Tittonell, 2014) in recognition of the focus of the current interpretations of SI on the environmental performance of agriculture?

Even with an agro-ecological framing, questions remain as to what forms of ecological intensification are desired. The emphasis accorded by the interviewees on environment and economic dimensions resemble the arguments underpinning the 'Ecological Modernisation' (EM) school of thought (Hajer, 1995; Jänicke, 2008; Mol and Spaargaren, 2000; Mol, 2001) regarding the vision of economic growth in postmodern, industrial societies, such as the UK. In agriculture, EM manifests itself as a belief that modernism, which birthed the Green Revolution, can be turned back on itself, through the application of additional technologies, in order to address the various environmental problems that it has caused (Horlings and Marsden, 2011; Marsden, 2012). Examples of EM in practice include, the use of novel forms of renewable energy, increased efficiency as a pollution abatement and waste reduction strategy (Jänicke, 2008), and the production of 'environmentally friendly' goods and services (Dryzek, 1997). These innovations are believed to be driven by the interplay between government policy on one hand, and the greater awareness of the risk that environmental damage presents to corporate interests on the other (Jänicke, 2008). Nevertheless, some argue that the EM perspective is too 'top-down' in its approach, overly focused on the European context, and is used to repackage 'business-as-usual' capitalism. In short, it is just another type of 'green-washing', a criticism that has also been levelled at SI, for similar reasons (Collins and Chandrasekaran, 2012; Cook et al., 2015; Lewis-Brown and Lymberry, 2012). There is a suggestion that weak interpretations of the EM predominate, and that these fail to address underlying structural issues, such as, a lack of social justice. The weaker version of EM has manifest in agriculture as gains in terms of environmental sustainability, but also negatively as unintended social and cultural consequences. For example, the loss of agricultural employment, the marginalisation of traditional farming techniques, and the loss of farmer autonomy as supply chains become longer and more international (Horlings and Marsden, 2011). In contrast, stronger forms of EM have been suggested by focusing more on the structural changes and participatory processes required in order to effect lasting change (Christoff, 1996; Hajer, 1993; Horlings and Marsden, 2011).

Is it therefore possible for the meaning of 'sustainability' within the concept of SI to be considered in a context-specific manner, with the weighting of the different dimensions varying according to where SI is adopted? The interviewees in this investigation comprised UK stakeholders, expressing UK-centric opinions. Can the stakeholders' interpretation of SI manifest in this research - focusing more on production-based concerns and environmental sustainability - be acceptable in all contexts? It can be argued that many of the social con-

\footnotetext{
1 See: http://www.un.org/sustainabledevelopment/development-agenda/.

2 See: http://www.worldbank.org/en/topic/sustainabledevelopment/overview.

3 See: http://www.oecd.org/greengrowth/46530443.pdf.
} 
cerns surrounding agriculture are, although present in the UK, not as severe as in other countries, due to strong governance and welfare systems. Thus, in other countries and at other times, the interpretation of SI may be different. For example, social sustainability may take on more emphasis in countries with a high incidence of hunger and inequality. In these contexts environmental considerations may be perceived as a luxury, and accorded less consideration. In such a context will it then be appropriate for SI to aspire more for social sustainability goals rather than environmental, which has been a value predominant in post-modern industrialised nations (Abramson and Inglehart, 1992; Inglehart, 1990).

In addition to a skewed emphasis on the different attributes of sustainability, several other issues regarding SI indicators can be identified. Firstly, there were missing indicators, e.g. although the use of GMOs was suggested as an indicator, the regulatory frameworks required to make GM technologies implementable were not suggested. This is an important issue as the commercial application of GMOs in Europe is constrained by EU regulations. Secondly, a number of SI indicators were vaguely-defined making it difficult to ascertain which aspects of sustainability they could be plausible for, e.g., 'Access to multiple sources of information'. If this information could be used to increase yields, then it could be plausible for economic sustainability (possibly renamed as 'Access to multiple sources of information on how to increase yields'). However, if this information could be used to help farmers reduce their environmental footprint, then it could instead be plausible for environmental sustainability (possibly renamed as 'Access to multiple sources of information on environmental protection'). Consequently, these two newly defined indicators could lead to trade-offs, as increasing yields through intensification may not be compatible with increased environmental protection. Another example is 'Amount of financial capital invested in farm'. Where exactly the farmer invests capital will change the aspect of sustainability this indicator could be relevant for. A final example is the indicator 'Productivity'. This was mentioned by a large number of stakeholders as something that should increase under SI. However, the increase in productivity could be in terms of land, labour, livestock feed, or an aggregate measure (e.g., total factor productivity). These could lead to trade-offs, e.g., increased labour productivity could lead to reductions in agricultural employment (a threat to social sustainability) and the uptake of intensive agricultural practices could impact on environmental sustainability. It is likely that if such vagueness is not addressed it will continue to fuel the disagreements and confusions surrounding SI.

Thirdly, numerous trade-offs emerged as an important issue. In addition to the above examples, several other trade-offs can be identified. Examples include the extent of agricultural mechanisation versus agricultural employment. The stakeholders discussed this in the context of the degradation of the social fabric of rural areas as agricultural regions depopulate, versus the need to produce greater quantities of food, more quickly and cheaply through the use of mechanisation. That the former was more frequently mentioned than the later would seem to suggest that production-based concerns were considered more important, suggesting a willingness to pursue production to the detriment of some of the sustainability dimensions. The size of farms was another area of contention. The stakeholders could not agree whether bigger was indeed 'better', or whether small farms, which are considered vital for the social sustainability, still have a role to play. Trade-offs were also apparent when the interviewees considered the pros and cons of intensive, housed livestock systems. As discussed previously, there are financial, environmental, and ethical considerations on both sides of this debate. This raises a further question for consideration. Is it even feasible for all the dimensions of sustainability to be achieved equally and concurrently? The myriad of trade-offs that seem to be inherent among the various dimensions of sustainability suggest that choices may need to be made as to what kind of sustainability can practically be pursued.

The foregoing discussions reinforce the main argument that we have put forward at the beginning of this paper, that is, the need for continued, constructive dialogue between all the stakeholders concerned in order to develop a shared vision of SI. As shown, there are considerable differences in the way SI is interpreted by different stakeholder groups. Whilst, for example, stakeholders from the food industry and those identified as input suppliers placed an emphasis on economic considerations - such as the cost of production and the use of loss leader pricing by food retailers -, those from NGOs identified some unique indicators such as the value of small family farms and sites of cultural and historical importance to the social sustainability of agriculture. As such, a blueprint of SI based on a top-down approach, that relies only on the opinion of 'experts' is unlikely to result in acceptance and consensus while continuing to generate more confusion and scepticism. We suggest that in order to find the common ground between these various points of view, multi-stakeholder dialogue is necessary by taking into account the aforementioned questions.

\section{Uncited references}

Beck (1996,1992), Chamberlain et al. (2000), DEFRA (2017), Donald et al. (2006), Hillocks (2012).

\section{References}

Abramson, P.R., Inglehart, R., 1992. Generational replacement and value change in eight West European societies. Br. J. Polit. Sci. 22, 183-228.

Agrimetrics, 2017. About Us. http://www.agrimetrics.co.uk/about.html Accessed: 15/02/ 2017.

Altieri, M.A., 2004. Linking ecologists and traditional farmers in the search for sustainable agriculture. Front. Ecol. Environ. 2, 35. https://doi.org/10.2307/3868293.

Altieri, M.A., Toledo, V.M., 2011. The agroecological revolution in Latin America: rescuing nature, ensuring food sovereignty and empowering peasants. J. Peasant Stud. 38, 587-612. https://doi.org/10.1080/03066150.2011.582947.

Altieri, M.A., Funes-Monzote, F.R., Petersen, P., 2012. Agroecologically efficient agricultural systems for smallholder farmers: contributions to food sovereignty. Agron. Sustain. Dev. 32, 1-13. https://doi.org/10.1007/s13593-011-0065-6.

Anderies, J.M., Janssen, M.A., Ostrom, E., 2004. A framework to analyze the robustness of social-ecological systems from an institutional perspective. Ecol. Soc. 9, 18.

Ango, T.G., Börjeson, L., Senbeta, F., Hylander, K., 2014. Balancing ecosystem services and disservices: smallholder farmers' use and management of Forest and trees in an agricultural landscape in Southwestern Ethiopia. Ecol. Soc. 19, https://doi.org/10.5751/ ES-06279-190130.

Angus, A., Burgess, P.J., Morris, J., Lingard, J., 2009. Agriculture and land use: demand for and supply of agricultural commodities, characteristics of the farming and food industries, and implications for land use in the UK. Land Use Policy 26, S230-S242. https://doi.org/10.1016/j.landusepol.2009.09.020.

Anyamba, A., Small, J.L., Britch, S.C., Tucker, C.J., Pak, E.W., Reynolds, C.A., Crutchfield, J., Linthicum, K.J., 2014. Recent weather extremes and impacts on agricultural production and vector-borne disease outbreak patterns. PLoS One 9, e92538. https://doi. org $/ 10.1371$ journal.pone.0092538.

Aschemann-Witzel, J., de Hooge, I., Amani, P., Bech-Larsen, T., Oostindjer, M., 2015. Consumer-related food waste: causes and potential for action. Sustainability 7 , 6457-6477. https://doi.org/10.3390/su7066457.

Ayars, J.E., Phene, C.J., Hutmacher, R.B., Davis, K.R., Schoneman, R.A., Vail, S.S., Mead, R.M., 1999. Subsurface drip irrigation of row crops: a review of 15 years of research at the water management research laboratory. Agric. Water Manage. 42, 1-27.

Ayres, R.U., Van Den Bergh, J.C., Gowdy, J.M., et al., 1998. Weak Versus Strong Sustainability. Tinbergen Institute Discussion Papers. In: http://dare.ubvu.vu.nl/bitstream/ handle/1871/9295/98103.pdf?sequence=1, Accessed: 31/07/2017.

Barnes, A.P., Thomson, S.G., 2014. Measuring progress towards sustainable intensification: how far can secondary data go?. Ecol. Indic. 36, 213-220. https://doi.org/10.1016/j. ecolind.2013.07.001.

Basurto, X., Gelcich, S., Ostrom, E., 2013. The social-ecological system framework as a knowledge classificatory system for benthic small-scale fisheries. Glob. Environ. Change 23, 1366-1380. https://doi.org/10.1016/j.gloenvcha.2013.08.001.

Batáry, P., Dicks, L.V., Kleijn, D., Sutherland, W.J., 2015. The role of agri-environment schemes in conservation and environmental management: European Agri-environment schemes. Conserv. Biol. 29, 1006-1016. https://doi.org/10.1111/cobi.12536.

Batey, T., 2009. Soil compaction and soil management - a review. Soil Use Manage. 25, 335-345. https://doi.org/10.1111/j.1475-2743.2009.00236.x. 
Bechmann, M., 2005. The Phosphorus index Tool: For Assessing Phosphorus Transfer from Agricultural Areas in Norway. Norwegian University of Life Sciences, Department of Plant and Environmental Sciences, As, Norway.

Beck, U., 1992. Risk Society: Towards a New Modernity. Sage Publications, Inc, London, UK.

Beck,

1996 Beck U., World risk society as cosmopolitan society? Ecological questions in a framework of manufactured uncertainties, Theory Cult. Soc. 13 (1996) 1-32.

Beddington, J., 2009. QEII Conference Centre, London. Food, Energy, Water and the Climate: a Perfect Storm of Global Events? Presented at the Sustainable Development UK Annual Conference19 March 2009.

Bellamy, P.H., Loveland, P.J., Bradley, R.I., Lark, R.M., Kirk, G.J., 2005. Carbon losses from all soils across England and Wales 1978-2003. Nature 437, 245-248.

Benayas, J.M.R., Newton, A.C., Diaz, A., Bullock, J.M., 2009. Enhancement of biodiversity and ecosystem services by ecological restoration: a meta-analysis. Science 325 , 1121-1124. https://doi.org/10.1126/science.1172460.

Bernard, B., Lux, A., 2017. How to feed the world sustainably: an overview of the discourse on agroecology and sustainable intensification. Region. Environ. Change 17, 1279-1290. https://doi.org/10.1007/s10113-016-1027-y.

Biggs, J., 2007. Small-Scale Solutions for Big Water Problems. Pond Conservation: The Habitats Trust, Oxford, UK.

Bilotta, G.S., Brazier, R.E., Haygarth, P.M., 2007. The impacts of grazing animals on the quality of soils, vegetation, and surface waters in intensively managed grasslands. Advances in Agronomy. Elsevier, 237-280. https://doi.org/10.1016/ S0065-2113(06)94006-1.

Braun, A., Duveskog, D., 2011. The Farmer Field School Approach: History, Global Assessment and Success Stories. Background Paper for the IFAD Rural Poverty Report.

Braun, V., Clarke, V., 2012. Thematic analysis. In: Cooper, H., Camic, P.M., Long, D.L., Panter, A.T., Rindskopf, D., Sher, K.J. (Eds.), APA Handbook of Research Methods in Psychology Vol. 2: Research Designs: Quantitative, Qualitative, Neuropsychological, and Biological. American Psychological Association, Washington, pp. 57-71.

Breeze, T.D., Bailey, A.P., Balcombe, K.G., Potts, S.G., 2011. Pollination services in the UK: how important are honeybees?. Agric. Ecosyst. Environ. 142, 137-143. https://doi. org/10.1016/j.agee.2011.03.020.

Buckwell, A., Uhre, A.N., Williams, A., Polakova, J., Blum, W.E.H., Schiefer, J., Lair, G.J., Heissenhuber, A., Schie $\beta 1$, P., Kramer, C., Haber, W., 2014. The Sustainable Intensification of European Agriculture. A Review Sponsored by the RISE Foundation. The RISE Foundation, Brussels.

Burford, G., Hoover, E., Velasco, I., Janoušková, S., Jimenez, A., Piggot, G., Podger, D., Harder, M., 2013. Bringing the "Missing pillar" into sustainable development goals: towards intersubjective values-based indicators. Sustainability 5, 3035-3059. https:// doi.org/10.3390/su5073035.

Burgess, P.J., Morris, J., 2009. Agricultural technology and land use futures: the UK case. Land Use Policy 26, S222-S229. https://doi.org/10.1016/j.landusepol.2009.08.029.

Burt, S.L., Sparks, L., 2003. Power and competition in the UK retail grocery Market. Br. J. Manage. 14, 237-254. https://doi.org/10.1111/1467-8551.00377.

Burton, R.J.F., Walford, N., 2005. Multiple succession and land division on family farms in the South East of England: a counterbalance to agricultural concentration?. J. Rural Stud. 21, 335-347. https://doi.org/10.1016/j.jrurstud.2005.04.004.

Busari, M.A., Kukal, S.S., Kaur, A., Bhatt, R., Dulazi, A.A., 2015. Conservation tillage impacts on soil, crop and the environment. Int. Soil Water Conserv. Res. 3, 119-129. https://doi.org/10.1016/j.iswcr.2015.05.002.

Campbell, P.J., 2013. Declining European bee health: banning the neonicotinoids is not the answer. Outlooks Pest Manage. 24, 52-57.

Campbell, B.M., Thornton, P., Zougmoré, R., van Asten, P., Lipper, L., 2014. Sustainable intensification: what is its role in climate smart agriculture?. Curr. Opin. Environ. Sustain. 8, 39-43. https://doi.org/10.1016/j.cosust.2014.07.002.

Canfora, I., 2016. Is the short food supply chain an efficient solution for sustainability in food market?. Agric. Agric. Sci. Procedia 8, 402-407. https://doi.org/10.1016/j. aaspro.2016.02.036

Carey, P.D., Wallis, S., Chamberlain, P.D., Cooper, A., Emmett, B.A., Maskell, L.C., McCann, T., Murphy, J., Norton, L.R., Reynolds, B., Scott, W.A., Simpson, I.C., Smart, S.M., Ullyett, J.M., 2008. Countryside Survey: UK Results from 2007. NERC/Centre for Ecology \& Hydrology.

Carlsson, F., Frykblom, P., Lagerkvist, C.J., 2007. Consumer willingness to pay for farm animal welfare: mobile abattoirs versus transportation to slaughter. Eur. Rev. Agric. Econ. 34, 321-344. https://doi.org/10.1093/erae/jbm025.

Chamberlain, D.E., Fuller, R.J., Bunce, R.G.H., Duckworth, J.C., Shrubb, M., 2000. Changes in the abundance of farmland birds in relation to the timing of agricultural intensification in England and Wales. J. Appl. Ecol. 37, 771-788.

Chikowo, R., Zingore, S., Snapp, S., Johnston, A., 2014. Farm typologies, soil fertility, variability and nutrient management in smallholder farming in Sub-Saharan Africa. Nutr. Cycl. Agroecosyst. 100, 1-18.

Chiswell, H.M., 2014. The importance of next generation farmers: a conceptual framework to bring the potential successor into focus: the importance of next generation farmers. Geogr. Compass 8, 300-312. https://doi.org/10.1111/gec3.12131.

Choi, H.C., Sirakaya, E., 2006. Sustainability indicators for managing community tourism. Tour. Manage. 27, 1274-1289. https://doi.org/10.1016/j.tourman.2005.05.018.

Christoff, P., 1996. Ecological modernisation, ecological modernities. Environ. Polit. 5, 476-500.

Cogliani, C., Goossens, H., Greko, C., 2011. Restricting antimicrobial use in food animals: lessons from Europe. Microbe 6, 274.
Collins, E.D., Chandrasekaran, K., 2012. A Wolf in Sheep's Clothing? An Analysis of the "Sustainable Intensification" of Agriculture. Friends of the Earth International, Amsterdam, The Netherlands.

Conway, G., 2000. Genetically modified crops: risks and promise. Conserv. Ecol. 4, https: //doi.org/10.5751/ES-00157-040102.

Conway, G., Toenniessen, G., 1999. Feeding the world in the twenty-first century. Nature 402, C55.

Cook, S., Silici, L., Adolph, B., Walker, S., 2015. Sustainable Intensification Revisited. IIED Brief. Pap 1-4.

CSF Evidence Team, 2014. Catchment Sensitive Farming Evaluation Report - Phases 1 to 3 (2006 - 2014).

Danfeng, S., Dawson, R., Baoguo, L., 2006. Agricultural causes of desertification risk in Minqin, China. J. Environ. Manage. 79.

Daniel, T.C., Muhar, A., Arnberger, A., Aznar, O., Boyd, J.W., Chan, K.M.A., Costanza, R., Elmqvist, T., Flint, C.G., Gobster, P.H., Gret-Regamey, A., Lave, R., Muhar, S., Penker, M., Ribe, R.G., Schauppenlehner, T., Sikor, T., Soloviy, I., Spierenburg, M., Taczanowska, K., Tam, J., von der Dunk, A., 2012. Contributions of cultural services to the ecosystem services agenda. Proc. Natl. Acad. Sci. 109, 8812-8819. https://doi. org/10.1073/pnas.1114773109.

Davidova, S., Bailey, A., 2014. Roles of small and semi-subsistence farms in the EU. EuroChoices 13, 10-14.

de Vries, F.T., Bardgett, R.D., 2015. Biodiversity Climate Change. Impacts Report Card Technical Paper. Climate Change Effects on Soil Biota in the UK. Climate Change and Soil Biota. Biodiversity Report Card 16.

DEFRA, 2013. Future of Farming Review Report. Department for Environment, Food and Rural Affairs, London, UK.

DEFRA, 2013. Rural Housing Availability and Affordability, Department for Environment, Food and Rural Affairs, London, UK.

DEFRA, 2013. Catchment Based Approach: Improving the Quality of Our Water Environment. A Policy Framework to Encourage the Wider Adoption of an Integrated Catchment Based Approach to Improving the Quality of Our Water Environment, Department for Environment, Food and Rural Affairs, London, UK.

DEFRA, 2015. Farm Structure Survey 2013 : Focus on Agricultural Labour in England and the United Kingdom. Department for Environment, Food and Rural Affairs, London, UK.

DEFRA, 2016. Food Statistics Pocketbook 2016. Department for Environment, Food and Rural Affairs, London, UK, Department for Environment, Food and Rural Affairs.

DEFRA, 2017. Sustainable Intensification Platform. Department for Environment, Food and Rural Affairs, London, UK.

DEFRA, Natural England, Rural Payments Agency, 2015. 2010 to 2015 Government Policy: Food and Farming Industry. Department for Environment, Food and Rural Affairs, London, UK.

DEFRA SIP, 2015. SIP Scene. The Newsletter of the Sustainable Intensification Research Platform. Spring/Summer 2015. Department for Environment, Food and Rural Affairs, London, UK.

DEFRA SIP, 2016. SIP Scene. The Newsletter of the Sustainable Intensification Research Platform. Autumn 2016. Department for Environment, Food and Rural Affairs, London, UK.

Department for Environment, Food and Rural Affairs, Department of Agriculture, Environment and Rural Affairs (Northern Ireland), Welsh Assembly, The Department for Rura Affairs and Heritage, The Scottish Government, Rural and Environment Research and Analysis Directorate, 2016. Agriculture in the UK, 2015. Department for Environment, Food and Rural Affairs, Belfast, N.I.

Department of Agriculture and Rural Development, 2016. The Agricultural Census in Northern Ireland. Results for June 2015. Department of Agriculture and Rural Development, policy and economics division, Belfast, N.I.

Dillon, E.J., Hennessy, T., Buckley, C., Donnellan, T., Hanrahan, K., Moran, B., Ryan, M. et al., 2014. The sustainable intensification of the Irish dairy sector. AgroParisTech, Paris, France. Contributed Paper Presented at the 88th Annual Conference of the Agricultural Economics Society17p.

Dobbs, T.L., Pretty, J., 2004. Agri-environmental stewardship schemes and "multifunctionality". Rev. Agric. Econ. 26, 220-237.

Dobbs

and

Pretty

2008. T.L. Dobbs, J. Pretty, Case study of agri-environmental payments: The United Kingdom, Ecol. Econ. 65 (2008) 765-775, https://doi.org/10.1016/j.ecolecon. 2007.07.030.

Donald, P.F., Green, R.E., Heath, M.F., 2001. Agricultural intensification and the collapse of Europe's farmland bird populations. Proc. R. Soc. B Biol. Sci. 268, 25-29. https:// doi.org/10.1098/rspb.2000.1325.

Donald, P.F., Sanderson, F.J., Burfield, I.J., van Bommel, F.P.J., 2006. Further evidence of continent-wide impacts of agricultural intensification on European farmland birds, 1990-2000. Agric. Ecosyst. Environ. 116, 189-196. https://doi.org/10.1016/j.agee. 2006.02.007

Dorward, A., Chirwa, E., 2011. The Malawi agricultural input subsidy programme: 2005/ 06 to 2008/09. Int. J. Agric. Sustain. 9, 232-247. https://doi.org/10.3763/ijas.2010. 0567.

Douthwaite, B., Kuby, T., van de Fliert, E., Schulz, S., 2003. Impact pathway evaluation: an approach for achieving and attributing impact in complex systems. Agric. Syst. 78, 243-265.

Dryzek, J., 1997. The Politics of the Earth: Environmental Discourses. Oxford University Press, Oxford, UK. 
Dungait, J.A.J., Cardenas, L.M., Blackwell, M.S.A., Wu, L., Withers, P.J.A., Chadwick, D.R., Bol, R., Murray, P.J., Macdonald, A.J., Whitmore, A.P., Goulding, K.W.T., 2012. Advances in the understanding of nutrient dynamics and management in UK agriculture. Sci. Total Environ. 434, 39-50. https://doi.org/10.1016/j.scitotenv.2012.04.029.

Eisenstein, M., 2015. Pesticides: seeking answers amid a toxic debate. Nature 521, S 52-55.

Elliott, J., Firbank, L.G., Drake, B., Cao, Y., Gooday, R., 2013. Exploring the Concept of Sustainable Intensification. Land Use Policy Groups LUPG. The UK statutory conservation, countryside and environment agencies, West Bromwich.

Fair Trade Advocacy Office, 2014. Who's Got the Power? Tackling Imbalances in Agricultural Supply Chains. A Study About Power Concentration and Unfair Trading Practices in Agricultural Supply Chains. Fair Trade Advocacy Office, Brussels, Belgium.

FAO, 2011. Save and Grow. A Policymaker's Guide to the Sustainable Intensification of Smallholder Crop Production. Food and Agriculture Organisation of the UN, Rome

Fearne, A., Duffy, R., Hornibrook, S., 2005. Justice in UK supermarket buyer-supplier relationships: an empirical analysis. Int. J. Retail Distrib. Manage. 33, 570-582. https:// doi.org/10.1108/09590550510608377.

Fischer, J., Brosi, B., Daily, G.C., Ehrlich, P.R., Goldman, R., Goldstein, J., Lindenmayer, D.B., Manning, A.D., Mooney, H.A., Pejchar, L., Ranganathan, J., Tallis, H., 2008. Should agricultural policies encourage land sparing or wildlife-friendly farming?. Front. Ecol. Environ. 6, 380-385. https://doi.org/10.1890/070019.

Fischer, J., Abson, D.J., Butsic, V., Chappell, M.J., Ekroos, J., Hanspach, J., Kuemmerle, T., Smith, H.G., von Wehrden, H., 2014. Land sparing versus land sharing: moving forward: land sparing versus land sharing. Conserv. Lett. 7, 149-157. https://doi.org/ $10.1111 /$ conl.12084

Foley, J.A., Ramankutty, N., Brauman, K.A., Cassidy, E.S., Gerber, J.S., Johnston, M., Mueller, N.D., O'Connell, C., Ray, D.K., West, P.C., Balzer, C., Bennett, E.M., Carpenter, S.R., Hill, J., Monfreda, C., Polasky, S., Rockström, J., Sheehan, J., Siebert, S., Tilman, D., Zaks, D.P.M., 2011. Solutions for a cultivated planet. Nature 478, 337-342. https://doi.org/10.1038/nature10452.

Food Ethics Council (Great Britain), 2007. Meat Consumption, Trends and Environmental Implications. A Report of the Business Forum Meeting on 20th November 2007. Food Ethics Council (Great Britain).

Food Ethics Council (Great Britain), 2010. Food Justice: the Report of the Food and Fairness Inquiry. Food Ethics Council, Brighton.

Food Ethics Council (Great Britain), 2012. Sustainable Intensification, Unravelling the Rhetoric. Food Ethics, the magazine of the Food Ethics Council. Food Ethics Council, Brighton, UK.

Foresight, 2011. Foresight. The Future of Food and Farming. Final Project Report. The Government Office for Science, London, UK.

Fraser, C.E., 2005. Farming and mental health problems and mental illness. Int. J. Soc. Psychiatry 51, 340-349. https://doi.org/10.1177/0020764005060844.

Frison, E.A., Cherfas, J., Hodgkin, T., 2011. Agricultural biodiversity is essential for a sustainable improvement in food and nutrition security. Sustainability 3, 238-253. https: //doi.org/10.3390/su3010238.

Game and Wildlife Conservation Trust, 2017. Big Farmland Bird Count. In: https://www. gwct.org.uk/farming/big-farmland-bird-count/, Accessed: 19/0/2017.

Garnett, T., Godfray, H.C.J., 2012. Sustainable Intensification in Agriculture. Navigating a Course Through Competing Food System Priorities. A Report on a Workshop. Food, Climate Research Network and the Oxford Martin Programme on the Future of Food. University of Oxford, UK.

Garnett, T., Appleby, M.C., Balmford, A., Bateman, I.J., Benton, T.G., Bloomer, P., Burlingame, B., Dawkins, M., Dolan, L., Fraser, D., et al., 2013. Sustainable intensification in agriculture: premises and policies. Science 341, 33-34.

Geels, F.W., 2010. Ontologies, socio-technical transitions (to sustainability), and the multi-level perspective. Res. Policy 39, 495-510. https://doi.org/10.1016/j.respol. 2010.01.022.

George, R., McFarlane, D., Nulsen, B., 1997. Salinity threatens the viability of agriculture and ecosystems in Western Australia. Hydrol. J. 5, 6-21.

Gliessman, S., 2014. Is there sustainability in "Sustainable intensification"?. Agroecol. Sustain. Food Syst. 38, 993-994. https://doi.org/10.1080/21683565.2014.939800.

Godfray, H.C.J., 2015. The debate over sustainable intensification. Food Secur. 7, 199-208. https://doi.org/10.1007/s12571-015-0424-2.

Godfray, H.C.J., Beddington, J.R., Crute, I.R., Haddad, L., Lawrence, D., Muir, J.F., Pretty, J., Robinson, S., Thomas, S.M., Toulmin, C., 2010. Food security: the challenge of feeding 9 billion people. Science 327, 812-818. https://doi.org/10.1126/science. 1185383.

Godfray, H.C.J., Blacquiere, T., Field, L.M., Hails, R.S., Petrokofsky, G., Potts, S.G., Raine, N.E., Vanbergen, A.J., McLean, A.R., 2014. A restatement of the natural science evidence base concerning neonicotinoid insecticides and insect pollinators. Proc. R. Soc. B Biol. Sci. 281, https://doi.org/10.1098/rspb.2014.0558, 20140558-20140558.

Goodman, L.A., 1961. Snowball sampling. Ann. Math. Stat. 32, 148-170.

Grando, S., McGee, R.J., 1990. Utilization of barley landraces in a breeding program. Biotic Stresses of Barley in Arid and Semi-Arid Environments.

Graves, A.R., Morris, J., Deeks, L.K., Rickson, R.J., Kibblewhite, M.G., Harris, J.A., Farewell, T.S., Truckle, I., 2015. The total costs of soil degradation in England and Wales. Ecol. Econ. 119, 399-413. https://doi.org/10.1016/j.ecolecon.2015.07.026.

Gregoire, A., 2002. The mental health of farmers. Occup. Med. 52, 471-476.

Gross, M., 2013. EU ban puts spotlight on complex effects of neonicotinoids. Curr. Biol. 23, R462-R464.
Gunton, R.M., Firbank, L.G., Inman, A., Winter, D.M., 2016. How scalable is sustainable intensification?. Nat. Plants 2, 16065. https://doi.org/10.1038/nplants.2016.65.

Hajer, M., 1993. Discourse coalitions and the institutionalisation of practice: the case of acid rain in Great Britain. The Argumentative Turn in Policy Analysis and Planning. Duke University Press, Durham, NC.

Hajer, M., 1995. The Politics of Environmental Discourse: Ecological Modernisation and the Policy Process. Oxford University Press, Oxford, UK.

Halliday, A., Glaser, M., 2011. A management perspective on social ecological systems: a generic system model and its application to a case study from Peru. Human Ecol. Rev. $18,1-18$.

Hanspach, J., Abson, D.J., French Collier, N., Dorresteijn, I., Schultner, J., Fischer, J., 2017. From trade-offs to synergies in food security and biodiversity conservation. Front. Ecol. Environ. 15, 489-494. https://doi.org/10.1002/fee.1632.

Hazell, P., Poulton, C., Wiggins, S., Dorward, A., 2010. The future of small farms: trajectories and policy priorities. World Dev. 38, 1349-1361. https://doi.org/10.1016/j. worlddev.2009.06.012.

Hernández-Morcillo, M., Plieninger, T., Bieling, C., 2013. An empirical review of cultural ecosystem service indicators. Ecol. Indic. 29, 434-444. https://doi.org/10.1016/ j.ecolind.2013.01.013.

Hillocks, R.J., 2012. Farming with fewer pesticides: EU pesticide review and resulting challenges for UK agriculture. Crop Prot. 31, 85-93. https://doi.org/10.1016/j. cropro.2011.08.008.

Hine, R., Pretty, J., 2008. Feed Your Senses': The Effects of Visiting a LEAF Farm. Report for LEAF (UK) as Part of Open Farm Sunday. In: http://www.openfarmsunday.org/ resources/000/288/286/Leaf_Final_report.pdf, Accessed: 01/09/2016.

Hingley, M.K., 2005. Power imbalance in UK Agri-food supply channels: learning to live with the supermarkets?. J. Market. Manage. 21, 63-88. https://doi.org/10.1362/ 0267257053166758 .

Hinkel, J., Cox, M.E., Schlüter, M., Binder, C.R., Falk, T., 2015. A diagnostic procedure for applying the social-ecological systems framework in diverse cases. Ecol. Soc. 20, https: //doi.org/10.5751/ES-07023-200132.

Hoffmann, I., 2011. Livestock biodiversity and sustainability. Livest. Sci. 139, 69-79. https://doi.org/10.1016/j.livsci.2011.03.016.

Hoisington, D., Khairallah, M., Reeves, T., Ribaut, Skomand, B., Taba, S., Warburton, M., 1999. Plant genetic resources: what can they contribute towards increased crop productivity?. Proc. Natl. Acad. Sci. U. S. A. 96, 5937-5943.

Holland, J.M., 2004. The environmental consequences of adopting conservation tillage in Europe: reviewing the evidence. Agric. Ecosyst. Environ. 103, 1-25. https://doi.org/ 10.1016/j.agee.2003.12.018.

Holzworth, D.P., Huth, N.I., de Voil, P.G., Zurcher, E.J., Herrmann, N.I., McLean, G., Chenu, K., van Oosterom, E.J., Snow, V., Murphy, C., Moore, A.D., Brown, H., Whish, J.P.M., Verrall, S., Fainges, J., Bell, L.W., Peake, A.S., Poulton, P.L., Hochman, Z., Thorburn, P.J., Gaydon, D.S., Dalgliesh, N.P., Rodriguez, D., Cox, H., Chapman, S. Doherty, A., Teixeira, E., Sharp, J., Cichota, R., Vogeler, I., Li, F.Y., Wang, E., Hammer, G.L., Robertson, M.J., Dimes, J.P., Whitbread, A.M., Hunt, J., van Rees, H., McClelland, T., Carberry, P.S., Hargreaves, J.N.G., MacLeod, N., McDonald, C., Harsdorf, J., Wedgwood, S., Keating, B.A., 2014. APSIM - evolution towards a new generation of agricultural systems simulation. Environ. Modell. Softw. 62, 327-350. https://doi. org/10.1016/j.envsoft.2014.07.009.

Horlings, L.G., Marsden, T.K., 2011. Towards the real green revolution? Exploring the conceptual dimensions of a new ecological modernisation of agriculture that could 'feed the world'. Glob. Environ. Change 21, 441-452. https://doi.org/10.1016/j.gloenvcha 2011.01.004.

Horrigan, L., Lawrence, R.S., Walker, P., 2002. How sustainable agriculture can address the environmental and human health harms of industrial agriculture. Environ. Health Perspect. 110, 445-456

Hughes, L., Hermans, P., Morgan, K., 2008. Risk factors for the use of prescription antibiotics on UK broiler farms. J. Antimicrob. Chemother. 61, 947-952. https://doi.org/ 10.1093/jac/dkn017.

Hulme, M.F., Vickery, J.A., Green, R.E., Phalan, B., Chamberlain, D.E., Pomeroy, D.E., Nalwanga, D., Mushabe, D., Katebaka, R., Bolwig, S., Atkinson, P.W., 2013. Conserving the birds of Uganda's banana-coffee arc: land sparing and land sharing compared PLoS One 8, e54597. https://doi.org/10.1371/journal.pone.0054597.

Hunter, M.C., Smith, R.G., Schipanski, M.E., Atwood, L.W., Mortensen, D.A., 2017. Agriculture in 2050: recalibrating targets for sustainable intensification. BioScience 67, 386-391. https://doi.org/10.1093/biosci/bix010.

Hutchins, M.J., Sutherland, J.W., 2008. An exploration of measures of social sustainability and their application to supply chain decisions. J. Clean. Prod. 16, 1688-1698. https: //doi.org/10.1016/j.jclepro.2008.06.001.

Hutchinson, J.J., Campbell, C.A., Desjardins, R.L., 2007. Some perspectives on carbon sequestration in agriculture. Agric. For. Meteorol. 142, 288-302. https://doi.org/10. 1016/j.agrformet.2006.03.030.

Ilbery, B., Maye, D., Watts, D., Holloway, L., 2010. Property matters: agricultural restructuring and changing landlord-tenant relationships in England. Geoforum 41, 423-434. https://doi.org/10.1016/j.geoforum.2009.11.009.

Inger, R., Gregory, R., Duffy, J.P., Stott, I., Voříšek, P., Gaston, K.J., 2015. Common European birds are declining rapidly while less abundant species' numbers are rising. Ecol. Lett. 18, 28-36. https://doi.org/10.1111/ele.12387.

Inglehart, R., 1990. Culture Shift in Advanced Industrial Society. Princeton University Press, Princeton N.J.

Ingram, J., Kirwan, J., 2011. Matching new entrants and retiring farmers through farm joint ventures: insights from the fresh start initiative in Cornwall, UK. Land Use Policy 28, 917-927. https://doi.org/10.1016/j.landusepol.2011.04.001. 
International Food Policy Research Institute, 2002. Green Revolution Curse or Blessing?. International Food Policy Research Institute, Washington D.C., USA.

Islam, M.M., Barnes, A., Toma, L., 2013. An investigation into climate change scepticism among farmers. J. Environ. Psychol. 34, 137-150. https://doi.org/10.1016/j.jenvp. 2013.02.002.

Jänicke, M., 2008. Ecological modernisation: new perspectives. J. Clean. Prod. 16, 557-565. https://doi.org/10.1016/j.jclepro.2007.02.011.

Johnson, J.M.-F., Franzluebbers, A.J., Weyers, S.L., Reicosky, D.C., 2007. Agricultural opportunities to mitigate greenhouse gas emissions. Environ. Pollut. 150, 107-124. https://doi.org/10.1016/j.envpol.2007.06.030.

Jones, J.W., Hoogenboom, G., Porter, C.H., Boote, K.J., Batchelor, W.D., Hunt, L.A., Wilkens, P.W., Singh, U., Gijsman, A.J., Ritchie, J.T., 2003. The DSSAT cropping system model. Eur. J. Agron. 18, 235-265.

Jordan, N.R., Davis, A.S., 2015. Middle-Way strategies for sustainable intensification of agriculture. BioScience 65, 513-519. https://doi.org/10.1093/biosci/biv033.

Keating, B.A., Carberry, P.S., Hammer, G.L., Probert, M.E., Robertson, M.J., Holzworth, D., Huth, N.I., Hargreaves, J.N., Meinke, H., Hochman, Z., et al., 2003. An overview of APSIM, a model designed for farming systems simulation. Eur. J. Agron. 18, 267-288.

Kirwan, J., Maye, D., Brunori, G., 2017. Acknowledging complexity in food supply chains when assessing their performance and sustainability. J. Rural Stud. 52, 21-32. https: //doi.org/10.1016/j.jrurstud.2017.03.008.

Kleijn, D., Sutherland, W.J., 2003. How effective are European agri-environment schemes in conserving and promoting biodiversity?. J. Appl. Ecol. 40, 947-969.

Klein, A.-M., Vaissiere, B.E., Cane, J.H., Steffan-Dewenter, I., Cunningham, S.A., Kremen, C., Tscharntke, T., 2007. Importance of pollinators in changing landscapes for world crops. Proc. R. Soc. B Biol. Sci. 274, 303-313. https://doi.org/10.1098/rspb.2006. 3721.

Kotb, T.H.S., Watanabe, T., Ogino, Y., Tanji, K.K., 2000. Soil salinization in the Nile Delta and related policy issues in Egypt. Agric. Water Manage. 43, 239-261.

Kummu, M., de Moel, H., Porkka, M., Siebert, S., Varis, O., Ward, P.J., 2012. Lost food, wasted resources: global food supply chain losses and their impacts on freshwater, cropland, and fertiliser use. Sci. Total Environ. 438, 477-489. https://doi.org/10. 1016/j.scitotenv.2012.08.092.

Lal, R., 2004. Soil carbon sequestration impacts on global climate change and food security. Science 304, 1623-1627.

Lal, R., 2004. Soil carbon sequestration to mitigate climate change. Geoderma 123, 1-22. https://doi.org/10.1016/j.geoderma.2004.01.032.

Lal, R., Follett, R.F., Stewart, B.A., Kimble, J.M., 2007. Soil carbon sequestration to mitigate climate change and advance food security. Soil Sci. 172, 943-956.

Lee, T.H., Hsieh, H.-P., 2016. Indicators of sustainable tourism: a case study from A Taiwan's wetland. Ecol. Indic. 67, 779-787. https://doi.org/10.1016/j.ecolind.2016.03. 023.

Lemaire, G., Franzluebbers, A., Carvalho, P.C., de, F., Dedieu, B., 2014. Integrated crop-livestock systems: strategies to achieve synergy between agricultural production and environmental quality. Agric. Ecosyst. Environ. 190, 4-8. https://doi.org/10. 1016/j.agee.2013.08.009.

Lescourret, F., Magda, D., Richard, G., Adam-Blondon, A.-F., Bardy, M., Baudry, J., Doussan, I., Dumont, B., Lefèvre, F., Litrico, I., Martin-Clouaire, R., Montuelle, B., Pellerin, S., Plantegenest, M., Tancoigne, E., Thomas, A., Guyomard, H., Soussana, J.-F., 2015. A social-ecological approach to managing multiple agro-ecosystem services. Curr. Opin. Environ. Sustain. 14, 68-75. https://doi.org/10.1016/j.cosust.2015.04.001.

Leventon, J., Schaal, T., Velten, S., Dänhardt, J., Fischer, J., Abson, D.J., Newig, J., 2017. Collaboration or fragmentation? Biodiversity management through the common agricultural policy. Land Use Policy 64, 1-12. https://doi.org/10.1016/j.landusepol.2017. 02.009 .

Levrel, H., Kerbiriou, C., Couvet, D., Weber, J., 2009. OECD pressure-state-response indicators for managing biodiversity: a realistic perspective for a French biosphere reserve. Biodivers. Conserv. 18, 1719-1732. https://doi.org/10.1007/ s10531-008-9507-0.

Lewis-Brown, E., Lymberry, P., 2012. Sustainable Intensification - an Oxymoron. Compassion in World Farming, Godalming, Surrey, UK.

Linking Environment and Farming, 2017. LEAF Open Farm Sunday. In: https://leafuk.org/ Accessed: 18/05/2018.

Lobley, M., 2010. Succession in the family farm business. J. Farm. Manage. 13, 839-851.

Loos, J., Abson, D.J., Chappell, M.J., Hanspach, J., Mikulcak, F., Tichit, M., Fischer, J. 2014. Putting meaning back into "sustainable intensification". Front. Ecol. Environ. 12, 356-361. https://doi.org/10.1890/130157.

Lovett, A.A., Sünnenberg, G.M., Richter, G.M., Dailey, A.G., Riche, A.B., Karp, A., 2009. Land use implications of increased biomass production identified by GIS-based suitability and yield mapping for miscanthus in England. BioEnergy Res. 2, 17-28. https: //doi.org/10.1007/s12155-008-9030-x.

Mahon, N., McGuire, S., Islam, M.M., 2016. Why bother with Bere? An investigation into the drivers behind the cultivation of a landrace barley. J. Rural Stud. 45, 54-65. https: //doi.org/10.1016/j.jrurstud.2016.02.017.

Mahon, N., Crute, I., Simmons, E., Islam, M.M., 2017. Sustainable intensification - "oxymoron" or "third-way"? A systematic review. Ecol. Indic. 74, 73-97. https://doi.org/ 10.1016/j.ecolind.2016.11.001.

Maier, L., Shobayashi, M., others, 2001. Multifunctionality: Towards an Analytical Framework. Organization for Economic.

Marsden, T., 2012. Towards a real sustainable Agri-food security and food policy: beyond the ecological fallacies?. Polit. Q. 83, 139-145
Marshall, E.J.P., 2004. Agricultural landscapes: field margin habitats and their interaction with crop production. J. Crop Improve. 12, 365-404. https://doi.org/10.1300/ J411v12n01 05 .

Marshall, E.J., Moonen, A., 2002. Field margins in northern Europe: their functions and interactions with agriculture. Agric. Ecosyst. Environ. 89, 5-21. https://doi.org/10. 1016/S0167-8809(01)00315-2.

Mascarenhas, M., Busch, L., 2006. Seeds of change: intellectual property rights, genetically modified soybeans and seed saving in the United States. Sociologia Ruralis 46, $122-138$.

Maye, D., Ilbery, B., Watts, D., 2009. Farm diversification, tenancy and CAP reform: results from a survey of tenant farmers in England. J. Rural Stud. 25, 333-342. https:// doi.org/10.1016/j.jrurstud.2009.03.003.

Mbzibain, A., Hocking, T.J., Tate, G., Ali, S., 2013. Renewable enterprises on UK farms: assessing levels of uptake, motivations and constraints to widespread adoption. Biomass Bioenergy 49, 28-37. https://doi.org/10.1016/j.biombioe.2012.11.028.

McGinnis, M.D., Ostrom, E., 2014. Social-ecological system framework: initial changes and continuing challenges. Ecol. Soc. 19, https://doi.org/10.5751/ES-06387-190230.

McShane, T.O., Hirsch, P.D., Trung, T.C., Songorwa, A.N., Kinzig, A., Monteferri, B., Mutekanga, D., Thang, H.V., Dammert, J.L., Pulgar-Vidal, M., Welch-Devine, M., Peter Brosius, J., Coppolillo, P., O'Connor, S., 2011. Hard choices: making trade-offs between biodiversity conservation and human well-being. Biol. Conserv. 144, 966-972. https://doi.org/10.1016/j.biocon.2010.04.038.

Merckx, T., Pereira, H.M., 2015. Reshaping agri-environmental subsidies: from marginal farming to large-scale rewilding. Basic Appl. Ecol. 16, 95-103. https://doi.org/10 1016/j.baae.2014.12.003

Mol, A.P.J., 2001. Globalization and Environmental Reform: The Ecological Modernization of the Global Economy. MIT Press, Cambridge, Massachusetts.

Mol, A.P., Spaargaren, G., 2000. Ecological modernisation theory in debate: a review. Environ. Polit. 9, 17-49.

Moss, S., 2013. Black-Grass (Alopecurus myosuroides). Rothamstead Research, Harpenden, Hertfordshire, UK.

Moss, S.R., Perryman, S.A.M., Tatnell, L.V., 2007. Managing herbicide-resistant blackgrass (Alopecurus Myosuroides): theory and practice. Weed. Technol. 21, 300-309. https:// doi.org/10.1614/WT-06-087.1.

Murgueitio, E., 1990. Intensive sustainable livestock production: an alternative to tropical deforestation. Ambio 19, 397-400.

Mwebaze, P., Marris, G.C., Budge, G.E., Brown, M., Potts, S.G., Breeze, T.D., MacLeod, A. 2010. Quantifying the Value of Ecosystem Services: A Case Study of Honeybee Pollination in the UK. Contributed Paper.

Myers, D., Hockaday, C., Martin, C., 2014. Views of Tenant Farmers and Agricultural Landlords on Aspects of the Agricultural Tenancy System. The Scottish Government Social Research Series, UK.

Nagendra, H., Ostrom, E., 2014. Applying the social-ecological system framework to the diagnosis of urban lake commons in Bangalore, India. Ecol. Soc. 19, https://doi.org/ 10.5751/ES-06582-190267.

Napolitano, F., Girolami, A., Braghieri, A., 2010. Consumer liking and willingness to pay for high welfare animal-based products. Trends Food Sci. Technol. 21, 537-543. https: //doi.org/10.1016/j.tifs.2010.07.012.

National Research Council, National Research Council (Eds.), 2010. Toward Sustainable Agricultural Systems in the 21st Century. National Academies Press, Washington, DC.

Neal, C., Jarvie, H.P., Neal, M., Hill, L., Wickham, H., 2006. Nitrate concentrations in river waters of the upper Thames and its tributaries. Sci. Total Environ. 365, 15-32. https: //doi.org/10.1016/j.scitotenv.2006.02.031

O'Neill Commission, 2016. Tackling Drug-Resistant Infections Globally: Final Report and Recommendations. The Review on Antimicrobial Resistance. Review on Antimicrobial Resistance, London, UK.

OECD, 2009. Evaluation of Agricultural Policy Reforms in Japan. Organisation for Economic Co-operation and Development.

Ollerton, J., Erenler, H., Edwards, M., Crockett, R., 2014. Extinctions of aculeate pollinators in Britain and the role of large-scale agricultural changes. Science 346, $1360-1362$.

Ostrom, E., 2007. Sustainable social-ecological systems: an impossibility?. San Francisco, USA. Paper Presented at the 2007 Annual Meetings of the American Association for the Advancement of Science, "Science and Technology for Wellbeing"15-19 February.

Ostrom, Elinor, 2007. A diagnostic approach for going beyond panaceas. Proc. Natl. Acad. Sci. 104, 15181-15187.

Ostrom, E., 2009. A General framework for analyzing sustainability of social-ecological systems. Science 325, 419-422. https://doi.org/10.1126/science.1172133.

Ostrom, E., Cox, M., 2010. Moving beyond panaceas: a multi-tiered diagnostic approach for social-ecological analysis. Environ. Conserv. 37, 451-463. https://doi.org/10. $1017 /$ S0376892910000834.

Ostrom, E., Janssen, M.A., Anderies, J.M., 2007. Going beyond panaceas. Proc. Natl. Acad. Sci. 104, 15176-15178.

Pachauri, R.K., Mayer, L., Intergovernmental Panel on Climate Change (Eds.), 2015. Climate Change 2014: Synthesis Report. Intergovernmental Panel on Climate Change, Geneva, Switzerland.

Parajuli, P., 2016. Searching for annapurna; or, cultivating earthbound regenerative abundance in the anthropocene. Religion and Sustainable Agriculture: World Spiritual Traditions and Food Ethics. University Press of Kentucky.

Parfitt, J., Barthel, M., Macnaughton, S., 2010. Food waste within food supply chains: quantification and potential for change to 2050. Philos. Trans. R. Soc. B Biol. Sci. 365, 3065-3081. https://doi.org/10.1098/rstb.2010.0126. 
Parliamentary Office of Science and Technology, 2010. Post Note 348. Insect Pollination. Parliamentary Office of Science and Technology, London, UK.

Pasam, R.K., Sharma, R., Walther, A., Özkan, H., Graner, A., Kilian, B., 2014. Genetic diversity and population structure in a legacy collection of spring barley landraces adapted to a wide range of climates. PLoS One 9, e1001223.

Pérez, V., Guerrero, F., González, M., Pérez, F., Caballero, R., 2013. Composite indicator for the assessment of sustainability: the case of Cuban nature-based tourism destinations. Ecol. Indic. 29, 316-324. https://doi.org/10.1016/j.ecolind.2012.12.027.

Perry, M., 2017. Why Family Farms Must Be Protected. Sustainable Food TrustIn: http:// sustainablefoodtrust.org/articles/family-farms-protected/, Accessed: 23/01/2017.

Petersen, B., Snapp, S., 2015. What is sustainable intensification? Views from experts. Land Use Policy 46, 1-10. https://doi.org/10.1016/j.landusepol.2015.02.002.

Peterson, A., 2016. Religion, local community, and sustainable agriculture. Religion and Sustainable Agriculture: World Spiritual Traditions and Food Ethics. University Press of Kentucky.

Phalan, B., Onial, M., Balmford, A., Green, R.E., 2011. Reconciling food production and biodiversity conservation: land sharing and land sparing compared. Science 333, 1289-1291. https://doi.org/10.1126/science.1208742.

Phalan, B., Green, R., Balmford, A., 2014. Closing yield gaps: perils and possibilities for biodiversity conservation. Philos. Trans. R. Soc. B Biol. Sci. 369, https://doi.org/10. 1098/rstb.2012.0285, 20120285-20120285.

Pickett, H., 2010. Farm Animal Cloning. Compassion in World Farming, Godalming, Surrey, UK.

Pimentel, D., Hepperly, P., Hanson, J., Douds, D., Seidel, R., 2005. Environmental, energetic and economic comparisons of organic and conventional farming systems. Bioscience 55 (7), 573-582.

Pingali, P.L., 2012. Green revolution: impacts, limits, and the path ahead. Proc. Natl. Acad. Sci. 109, 12302-12308. https://doi.org/10.1073/pnas.0912953109.

Pittelkow, C.M., Linquist, B.A., Lundy, M.E., Liang, X., van Groenigen, K.J., Lee, J., van Gestel, N., Six, J., Venterea, R.T., van Kessel, C., 2015. When does no-till yield more? A global meta-analysis. Field Crops Res. 183, 156-168. https://doi.org/10.1016/j.fcr. 2015.07.020.

Powell, J.P., Reinhard, S., 2016. Measuring the effects of extreme weather events on yields. Weather Clim. Extremes 12, 69-79. https://doi.org/10.1016/j.wace.2016.02. 003.

Prasuhn, V., 2012. On-farm effects of tillage and crops on soil erosion measured over 10 years in Switzerland. Soil. Tillage Res. 120, 137-146. https://doi.org/10.1016/j.still. 2012.01.002.

Pretty, J., 1995. Participatory learning for sustainable agriculture. World Dev. 23 (8), $1247-1263$.

Pretty, J.N., 1997. The sustainable intensification of agriculture. Natural Resources Forum. Wiley Online Library, 247-256.

Pretty, J.N., Brett, C., Gee, D., Hine, R.E., Mason, C.F., Morison, J.I.L., Raven, H., Rayment, M.D., Van der Bijl, G., 2000. An assessment of the total external costs of UK agriculture. Agric. Syst. 65, 113-136.

Pretty, J., Smith, G., Goulding, K.W.T., Groves, S.J., Henderson, I., Hine, R.E., King, V., van Oostrum, J., Pendlington, D.J., Vis, J.K., Walter, C., 2008. Multi-year assessment of Unilever's progress towards agricultural sustainability I: indicators, methodology and pilot farm results. Int. J. Agric. Sustain. 6, 37-62. https://doi.org/10.3763/ijas. 2007.0322.

Pretty, J., Sutherland, W.J., Ashby, J., Auburn, J., Baulcombe, D., Bell, M., Bentley, J., Bickersteth, S., Brown, K., Burke, J., et al., 2010. The top 100 questions of importance to the future of global agriculture. Int. J. Agric. Sustain. 8, 219-236.

Pretty, J., Toulmin, C., Williams, S., 2011. Sustainable intensification in African agriculture. Int. J. Agric. Sustain. 9, 5-24. https://doi.org/10.3763/ijas.2010.0583.

Prokopy, L.S., Floress, K., Klotthor-Weinkauf, D., Baumgart-Getz, A., 2008. Determinants of agricultural best management practice adoption: evidence from the literature. J. Soil Water Conserv. 63, 300.

QSR International, 2012. NVivo Qualitative Data Analysis Software; QSR International Pty Ltd. Version 10.

Raney, T., 2006. Economic impact of transgenic crops in developing countries. Curr. Opin. Biotechnol. 17, 174-178. https://doi.org/10.1016/j.copbio.2006.02.009.

Raynolds, L.T., 2000. Re-Embedding global agriculture: the international organic and fair trade movements. Agric. Hum. Values 17, 297-309.

Renting, H., Marsden, T.K., Banks, J., 2003. Understanding alternative food networks: exploring the role of short food supply chains in rural development. Environ. Plan. 35, 393-411.

Renting, H., Rossing, W.A.H., Groot, J.C.J., Van der Ploeg, J.D., Laurent, C., Perraud, D., Stobbelaar, D.J., Van Ittersum, M.K., 2009. Exploring multifunctional agriculture. A review of conceptual approaches and prospects for an integrative transitional framework. J. Environ. Manage. 90, S112-S123. https://doi.org/10.1016/j.jenvman.2008. 11.014

Renwick, A., Islam, M.M., Thomson, S., 2012. Power in global agriculture: economics, politics, and natural resources. Int. J. Agric. Manage. 2, 31. https://doi.org/10.5836/ ijam/2013-01-04

Reyes-García, V., Guèze, M., Luz, A.C., Paneque-Gálvez, J., Macía, M.J., Orta-Martínez, M., Pino, J., Rubio-Campillo, X., 2013. Evidence of traditional knowledge loss among a contemporary indigenous society. Evol. Hum. Behav. 34, 249-257. https://doi.org/ 10.1016/j.evolhumbehav.2013.03.002.

Rockström, J., Steffen, W., Noone, K., Persson, ^̊, Chapin, F.S., Lambin, E.F., Lenton, T.M., Scheffer, M., Folke, C., Schellnhuber, H.J., et al., 2009. A safe operating space for humanity. Nature 461, 472-475.
Rockström, J., Williams, J., Daily, G., Noble, A., Matthews, N., Gordon, L., Wetterstrand, H., DeClerck, F., Shah, M., Steduto, P., de Fraiture, C., Hatibu, N., Unver, O., Bird, J., Sibanda, L., Smith, J., 2016. Sustainable intensification of agriculture for human prosperity and global sustainability. Ambio https://doi.org/10.1007/s13280-016-0793-6.

Rodell, M., Velicogna, I., Famiglietti, J.S., 2009. Satellite-based estimates of groundwater depletion in India. Nature 460, 999-1002. https://doi.org/10.1038/nature08238.

Romm, J., 2011. Desertification: the next dust bowl. Nature 478, 450-451.

Rosegrant, M.W., 2003. Global food security: challenges and policies. Science 302, 1917-1919. https://doi.org/10.1126/science.1092958.

Rosset, P.M., Machín Sosa, B., Roque Jaime, A.M., Ávila Lozano, D.R., 2011. The Campesino -to- Campesino agroecology movement of ANAP in Cuba: social process methodology in the construction of sustainable peasant agriculture and food sovereignty. J. Peasant Stud. 38, 161-191. https://doi.org/10.1080/03066150.2010. 538584 .

Royal Society, 2009. Reaping the Benefits Science and the Sustainable Intensification of Global Agriculture. The Royal Society (London), London.

Rozema, J., Flowers, T., 2008. Crops for a salinized world. Science 322, 1478-1480.

Sayer, C., Shilland, E., Greaves, H., Dawson, B., Patmore, I., Emson, D., Alderton, E., Robinson, P., Andrews, K., Axmacher, J., et al., 2013. Managing Britain's ponds-conservation lessons from a Norfolk farm. Br. Wildl. 25, 21-28.

Schaich, H., Bieling, C., Plieninger, T., 2010. Linking ecosystem services with cultura landscape research. Gaia-Ecol. Perspect. Sci. Soc. 19, 269-277.

Sen, A., 1981. Poverty and Famines: An Essay on Entitlement and Deprivation. Clarendon Press; Oxford University Press, Oxford : New York.

Shannon, H.D., Motha, R.P., 2015. Managing weather and climate risks to agriculture in North America, Central America and the Caribbean. Weather Clim. Extremes 10, 50-56. https://doi.org/10.1016/j.wace.2015.10.006

Shelter, 2004. Priced Out: the Rising Cost of Rural Homes, Shelter Policy Library. Shelter, Edinburgh, UK.

Shobayashi, M., et al., 2003. Multifunctionality: The Policy Implications. Organization for Economic.

Singh, G., 2009. Salinity-related desertification and management strategies: Indian experience. Land Degrad. Dev. 20, 367-385.

Smith, P., Martino, D., Cai, Z., Gwary, D., Janzen, H., Kumar, P., McCarl, B., Ogle, S., O'Mara, F., Rice, C., 2007. Policy and technological constraints to implementation of greenhouse gas mitigation options in agriculture. Agric. Ecosyst. Environ. 118, 6-28. https://doi.org/10.1016/j.agee.2006.06.006.

Smith, P., Martino, D., Cai, Z., Gwary, D., Janzen, H., Kumar, P., McCarl, B., Ogle, S., O'Mara, F., Rice, C., Scholes, B., Sirotenko, O., Howden, M., McAllister, T., Pan, G., Romanenkov, V., Schneider, U., Towprayoon, S., Wattenbach, M., Smith, J., 2008 Greenhouse gas mitigation in agriculture. Philos. Trans. R. Soc. B Biol. Sci. 363, 789-813. https://doi.org/10.1098/rstb.2007.2184.

Smith, P., House, J.I., Bustamante, M., Sobocká, J., Harper, R., Pan, G., West, P.C., Clark, J.M., Adhya, T., Rumpel, C., Paustian, K., Kuikman, P., Cotrufo, M.F., Elliott, J.A., McDowell, R., Griffiths, R.I., Asakawa, S., Bondeau, A., Jain, A.K., Meersmans, J., Pugh, T.A.M., 2016. Global change pressures on soils from land use and management. Glob. Change Biol. 22, 1008-1028. https://doi.org/10.1111/gcb.13068.

Soini, K., Birkeland, I., 2014. Exploring the scientific discourse on cultural sustainability Geoforum 51, 213-223. https://doi.org/10.1016/j.geoforum.2013.12.001.

Stockdale, E.A., Watson, C.A., 2012. Managing Soil Biota to Deliver Ecosystem Services. Natural England Comissioned Reports, Number 100.

Stöckle, C.O., Donatelli, M., Nelson, R., 2003. CropSyst, a cropping systems simulation model. Eur. J. Agron. 18, 289-307.

Stöckle, C.O., Kemanian, A.R., Nelson, R.L., Adam, J.C., Sommer, R., Carlson, B., 2014 CropSyst model evolution: from field to regional to global scales and from research to decision support systems. Environ. Modell. Softw. 62, 361-369. https://doi.org/10. 1016/j.envsoft.2014.09.006

Strauss, D.M., 2009. The Application of TRIPS to GMOs: International Intellectual Property Rights and Biotechnology.

Struik, P., Kuyper, T., Brussaard, L., Leeuwis, C., 2014. Deconstructing and unpacking scientific controversies in intensification and sustainability: why the tensions in concepts and values?. Curr. Opin. Environ. Sustain. 8, 80-88. https://doi.org/10.1016/j.cosust. 2014.10.002.

Sutherland, W.J., Clout, M., Depledge, M., Dicks, L.V., Dinsdale, J., Entwistle, A.C., Fleishman, E., Gibbons, D.W., Keim, B., Lickorish, F.A., Monk, K.A., Ockendon, N., Peck, L.S., Pretty, J., Rockström, J., Spalding, M.D., Tonneijck, F.H., Wintle, B.C., 2015. A horizon scan of global conservation issues for 2015. Trends Ecol. Evol. 30, 17-24. https://doi.org/10.1016/j.tree.2014.11.002.

Swaminathan, M.S., Rengalakshmi, R., 2016. Impact of extreme weather events in Indian agriculture: enhancing the coping capacity of farm families. Mausam 67, 1-4.

Swetnam, R.D., Owen Mountford, J., Manchester, S.J., Broughton, R.K., 2004. Agri-environmental schemes: their role in reversing floral decline in the brue floodplain, Somerset, UK. J. Environ. Manage. 71, 79-93. https://doi.org/10.1016/j.jenvman.2004. 01.006.

Syngenta foundation for sustainable agriculture, 2016. Sustainable Intensification. In: http: //www.syngentafoundation.org/index.cfm?pageID =774, Accessed: 06/07/2016

Szúcs, E., Geers, R., Jezierski, T., Sossidou, E.N., Broom, D.M., 2012. Animal welfare in different human cultures, traditions and religious faiths. Asian Australas. J. Anim. Sci. 25, 1499-1506. https://doi.org/10.5713/ajas.2012.r.02

Tenenbaum, D.J., 2008. Food vs. fuel: diversion of crops could cause more hunger. Environ. Health Perspect. 116, A254. 
The Montpellier Panel, 2013. Sustainable Intensification: a New Paradigm for African Agriculture. Agriculture for Impact, London, UK.

Tilman, D., Cassman, K.G., Matson, P.A., Naylor, R., Polasky, S., 2002. Agricultural sustainability and intensive production practices. Nature 418, 671-677.

Tilman, D., Balzer, C., Hill, J., Befort, B.L., 2011. Global food demand and the sustainable intensification of agriculture. Proc. Natl. Acad. Sci. 108, 20260-20264. https://doi. org/10.1073/pnas.1116437108.

Tim Chamen, W.C., Moxey, A.P., Towers, W., Balana, B., Hallett, P.D., 2015. Mitigating arable soil compaction: a review and analysis of available cost and benefit data. Soil Tillage Res. 146, 10-25. https://doi.org/10.1016/j.still.2014.09.011.

Tittonell, P., 2014. Ecological intensification of agriculture-sustainable by nature. Curr. Opin. Environ. Sustain. 8, 53-61. https://doi.org/10.1016/j.cosust.2014.08.006.

Tonsor, G.T., Olynk, N., Wolf, C., 2009. Consumer preferences for animal welfare attributes: the case of gestation crates. J. Agric. Appl. Econ. 41, 713-730.

Tubiello, F.N., Salvatore, M., Cóndor Golec, R.D., Ferrara, A., Rossi, S., Biancalani, R., Federici, S., Jacobs, H., Flammini, A., 2014. Agriculture, Forestry and Other Land Use Emissions by Sources and Removals by Sinks. Rome, Italy.

Ucar, T., Hall, F.R., 2001. Windbreaks as a pesticide drift mitigation strategy: a review. Pest Manage. Sci. 57, 663-675. https://doi.org/10.1002/ps.341.

UK Biodiversity Action Plan, 2008. UK Biodiversity Action Plan Priority Habitat Descriptions: from: UK Biodiversity Action Plan; Priority Habitat Descriptions. Joint Nature Conservation Committee, Peterborough, UK.

UK Government, 2013. A UK Strategy for Agricultural Technologies. UK Government, London, UK.

UK Government, 2017. Agri-Tech Strategy. In: https://agritech.blog.gov.uk/, Accessed: $30 / 10 / 2017$.

United Nations, 1987. Our Common Future (The Brundtland Report). Oxford University Press.

van Berkel, D.B., Verburg, P.H., 2014. Spatial quantification and valuation of cultural ecosystem services in an agricultural landscape. Ecol. Indic. 37, 163-174. https://doi. org/10.1016/j.ecolind.2012.06.025.

Vandermeer, J., 1995. The ecological basis of alternative agriculture. Annu. Rev. Ecol. Syst. 26, 201-224.

Vanhonacker, F., Verbeke, W., Van Poucke, E., Tuyttens, F.A.M., 2008. Do citizens and farmers interpret the concept of farm animal welfare differently?. Livest. Sci. 116, 126-136. https://doi.org/10.1016/j.livsci.2007.09.017.

Vanlauwe, B., Coyne, D., Gockowski, J., Hauser, S., Huising, J., Masso, C., Nziguheba, G., Schut, M., Van Asten, P., 2014. Sustainable intensification and the African smallholder farmer. Curr. Opin. Environ. Sustain. 8, 15-22. https://doi.org/10.1016/j. cosust.2014.06.001.

Veteto, J.R., 2008. The history and survival of traditional heirloom vegetable varieties in the Southern Appalachian Mountains of Western North Carolina. Agric. Hum. Values 25, 121-134.

Vogt, J.M., Epstein, G.B., Mincey, S.K., Fischer, B.C., McCord, P., 2015. Putting the "E" in SES: unpacking the ecology in the Ostrom social-ecological system framework. Ecol. Soc. 20, https://doi.org/10.5751/ES-07239-200155.
Wachenheim, C., Rathge, R., 2000. Societal Perceptions of Agriculture (No. 449), Agribusiness and Applied Economics Report. Department of Agribusiness and Applied Economics Agricultural Experiment Station North Dakota State University, Fargo, ND.

Wasley, A., 2015. The Controversial "Mega-Dairies" that Alarm Campaigners and Divide a Struggling Sector of British Agriculture. The Independent.

Wasley, A., Harvey, F., Davies, M., Child, D., 2017. UK Has Nearly 800 Livestock Mega Farms, Investigation Reveals. The Guardian.

Wedderburn, P., 2017. Does the UK Really Want Mega-Farms?. The Telegraph.

Whaley, L., 2003. The future of native languages. Futures 35, 961-973. https://doi.org/ 10.1016/S0016-3287(03)00052-1.

Whitfield, S., Benton, T.G., Dallimer, M., Firbank, L.G., Poppy, G.M., Sallu, S.M., Stringer, L.C., 2015. Sustainability spaces for complex agri-food systems. Food Secur. 7, 1291-1297. https://doi.org/10.1007/s12571-015-0512-3.

Willock, J., Deary, I.J., Edwards-Jones, G., Gibson, G.J., McGregor, M.J., Sutherland, A., Dent, J.B., Morgan, O., Grieve, R., 1999. The role of attitudes and objectives in farmer decision making: business and environmentally-oriented behaviour in Scotland. J. Agric. Econ. 50, 286-303.

Willock, J., Deary, I.J., McGregor, M., Sutherland, A., Edwards-Jones, G., Morgan, O., Dent, B., Grieve, R., Gibson, G., Austin, E., 1999. Farmers' attitudes, objectives, behaviors, and personality traits: the Edinburgh study of decision making on farms. J. Vocation. Behav. 54, 5-36.

Winter, M., Lobley, M., 2016. Is There a Future for the Small Family Farm in the UK? Report to The Prince's Countryside Fund. Prince's Countryside Fund, London, UK.

Wise, T.A., 2004. The Paradox of Agricultural Subsidies: Measurement Issues, Agricultural Dumping, and Policy Reform.

Wood, P.J., Greenwood, M.T., Agnew, M.D., 2013. Pond biodiversity and habitat loss in the UK. Area 35, 206-216.

Woodley, E., Crowley, E., de Pryck, J.D., Carmen, A., 2006. Cultural Indicators of Indigenous Peoples' Food and Agro-Ecological Systems. SARD Initiative commissioned by FAO and the International India Treaty Council 1-104.

World Bank, 2013. World Bank Group Agriculture Action Plan 2013-2015. World Bank, New York, USA.

Worsley, A., Wang, W., Ridley, S., 2015. Australian adults' knowledge of Australian agriculture. Br. Food J. 117, 400-411. https://doi.org/10.1108/BFJ-07-2013-0175.

Wray, A., 2016. Agricultural Statistics and Climate Change 7th Edition, August 2016. DEFRA Agricultural Change and Environment Observatory Research Report No. 11 Department for Environment, Food and Rural Affairs, UK.

Zeigler, R.S., Mohanty, S., 2010. Support for international agricultural research: current status and future challenges. New Biotechnol. 27, 565-572. https://doi.org/10.1016/ j.nbt.2010.08.003.

Zepeda, L., 2001. Agricultural Investment and Productivity in Developing Countries. Food \& Agriculture Organisation of the United Nations, Rome, Italy.

Zhang, W., Ricketts, T.H., Kremen, C., Carney, K., Swinton, S.M., 2007. Ecosystem services and dis-services to agriculture. Ecol. Econ. 64, 253-260. https://doi.org/10.1016/j. ecolecon.2007.02.024. 